\title{
Geologia e arcabouço estrutural do Complexo Lagoa Real, vale do Paramirim, Centro-Oeste da Bahia
}

\author{
Simone Cerqueira Pereira Cruz', Fernando Flecha Alkmim², Carlson Matos Maia Leite ${ }^{3}$, \\ Hanna Jordt-Evangelista ${ }^{2}$, José Carlos Cunha ${ }^{4}$, Evando Carele Matos ${ }^{5}$, \\ Carlos Maurício Noce ${ }^{6}$ \& Moacir Moura Marinho ${ }^{4}$
}

\begin{abstract}
Resumo O Complexo Lagoa Real, constituído por meta-granitóides com idade de colocação em torno de 1,7 Ga, ocorre no vale do Paramirim e engloba as rochas denominadas genericamente de Granito São Timóteo e um conjunto de granitóides milonitizados em graus variados gerados no curso de uma deformação compressional sin-metamórfica. A análise estrutural permitiu identificar duas famílias de estruturas: uma compressiva, representada por zonas de cisalhamento, bandamento composicional, foliação milonítica e dobras; e outra distensiva, marcada pela nucleação de zonas de cisalhamento normais. As estruturas deformacionais identificadas assemelham-se com as que são encontradas no sinclinal de Ituaçu, onde afloram as formações Salitre e Bebedouro do Grupo Una. Como não foi encontrada uma trama mais antiga que a primária, sugere-se que a deformação do Complexo Lagoa Real ocorreu durante o Neoproterozóico.
\end{abstract}

Palavras-chave: aulacógeno, metamorfismo, orógeno, cráton, foliação.

\begin{abstract}
Geology and Structural Outline of the Lagoa Real Complex. The Lagoa Real Complex is constituted by $1.7 \mathrm{Ga}$ granitoids that occur along the Paramirim valley. The granitoids are formed by the São Timóteo Granite and a set of alkali-gneisses that were crystallized during a compressional sin-metamorphic deformation episode. The carried out structural analysis has identified two deformation patterns. The compressional episode is represented by shear zones, compositional layering, milonite foliation and folds. The extensional episode is characterized by the nucleation of normal shear zones. The geometric patterns of the finite deformation are similar to the ones that occur in the Ituaçu synclinal where the Salitre e Bebedouro formations of Una Group outcrop. An ancient geometric pattern was not found in the area; consequently we propose that the deformation episodes were related to the neoproterozoic Orogeny.
\end{abstract}

Keywords: aulacogen, metamorphism, orogen, craton, foliation.

INTRODUÇÃOO O Complexo Lagoa Real situa-se na porção setentrional do orógeno Araçuaí, cujos limites foram recentemente redefinidos por Alkmim (2004) a partir dos trabalhos de Cruz (2004) (Fig. 1). Chamase Orógeno Araçuaí a porção brasileira do Orógeno Araçuaí-Congo Ocidental, o qual constitui um domínio brasiliano de deformação, metamorfismo e granitogênese desenvolvido como uma incisão de forma linguóide entre os crátons do São Francisco e Congo (PedrosaSoares et al. 1992a, b, Pedrosa-Soares \& WiedemannLeonardos 2000). Em sua porção setentrional, o arcabouço estrutural do Orógeno Araçuaí é marcado por um conjunto de zonas de cisalhamento que foram geradas durante a interação entre duas entidades tectônicas: o Aulacógeno do Paramirim e o Orógeno Araçuaí (Cruz 2004, Cruz \& Alkmim 2006). O Aulacógeno do Paramirim (Pedrosa-Soares et al. 2001) corresponde a um par de riftes superpostos, cuja evolução teria se iniciado no Paleoproterozóico e evoluído até o Neoproterozóico (Schobbenhaus 1996, Danderfer Fo 2000). Possui como unidades de preenchimento, do topo para a base, o supergrupo São Francisco, de idade neoproterozóica (Misi \& Veizer 1996), e Espinhaço, de idade paleoproterozóica. O seu substrato é constituído por rochas mais antigas que $1,8 \mathrm{Ga}$ e pelo Complexo Lagoa Real.

O Complexo Lagoa Real (Costa et al. 1985) (Fig. 2) é constituído por meta-granitóides com idades em torno de 1,7 Ga (Turpin et al. 1988, Cordani et al. 1992), gnaisses e albititos da Suíte Intrusiva Lagoa Real (Arcanjo et al. 2000) e por um conjunto de diabásios, anfibolitos e charnoquitos que ocorrem intercalados com os litotipos daquela suíte. Abriga uma importante mineralização de urânio, de idade também conhecida (em torno de 960 Ma, Pimentel et al. 1994). A mineralização está hospedada em corpos lenticulares de albititos que, por sua vez, estão paralelizados a

1 - Instituto de Geociências, Universidade Federal da Bahia, Salvador (BA), Brasil. E-mail: simoneufba@gmail.com

2 - Departamento de Geologia, Universidade Federal de Ouro Preto, Ouro Preto (MG), Brasil. E-mail: ffalkmim@gmail.com

3 - PETROBRAS, Salvador (BA), Brasil. E-mail: cmmleite@petrobras.com.br

4 - Companhia Baiana de Pesquisa Mineral (Centro Administrativo da Bahia), Salvador (BA), E-mail: zecunha@cbpm.com.br

5 - Indústrias Nucleares do Brasil, Caetité (BA), Brasil. E-mail: carele@inb.br

6 - Departamento de Geologia, Instituto de Geociências, Universidade Federal de Minas Gerais, Belo Horizonte (MG), Brasil 


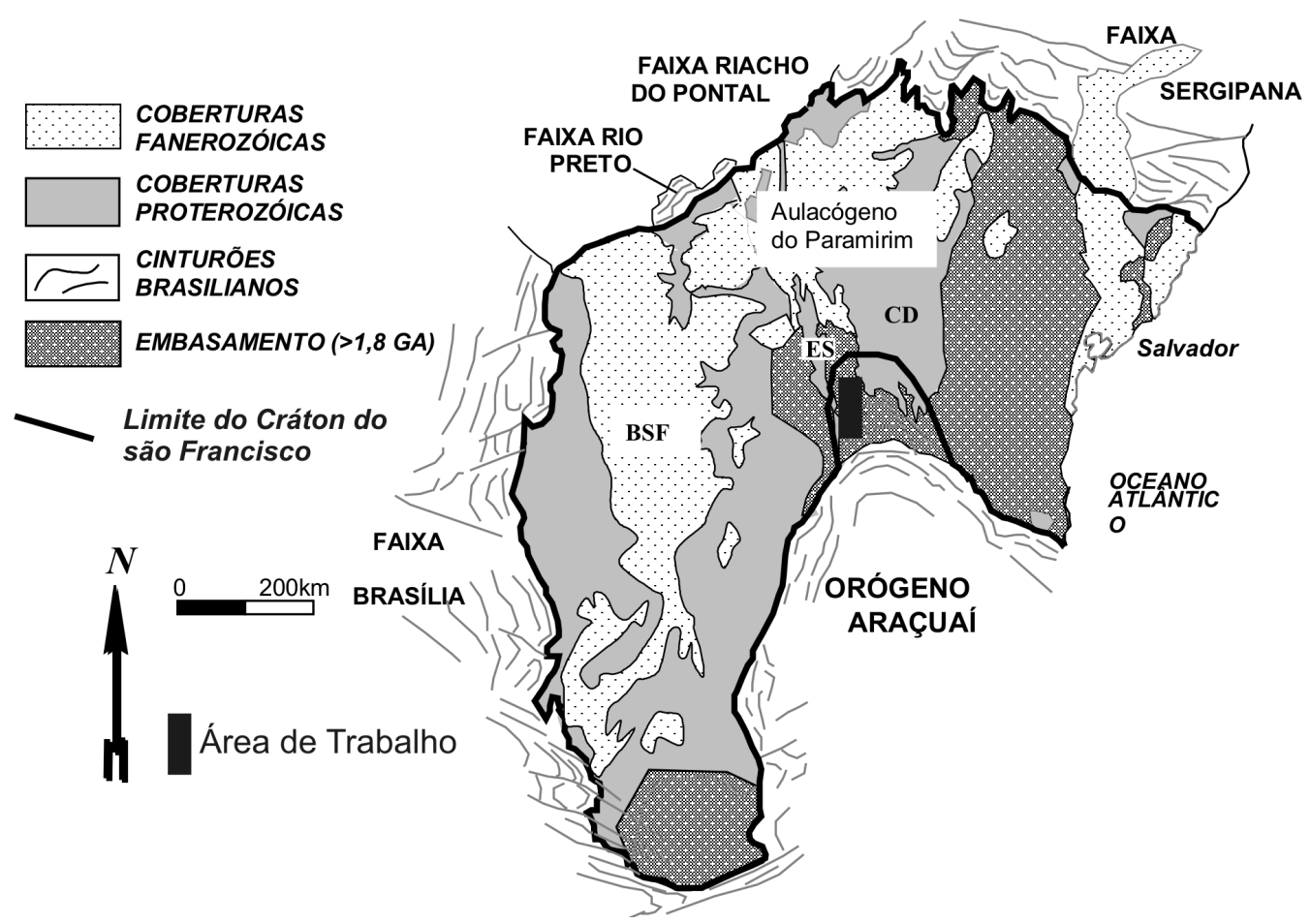

Figura 1 - Mapa tectônico simplificado da porção leste do Brasil, enfatizando o Cráton do São Francisco. CD-Chapada Diamantina, ES- Espinhaço Setentrional, BSF- Bacia do São Francisco. Modificado de Alkmim et al. (1993) e Alkmim (2004).

gnaisses gerados a partir da deformação dos granitos (Costa et al. 1985, Lobato 1985, Arcanjo et al. 2000, Cruz \& Alkmim 2002).

No Aulacógeno do Paramirim uma importante controvérsia refere-se à existência ou não de um evento deformacional que teria ocorrido durante o Mesoproterozóico. Se realmente ocorreu, o seu registro estrutural deverá ser encontrado nas unidades geológicas mais jovens que 1,8 Ga. O Complexo Lagoa Real (Fig. 2), com idade bem definida e representativo da fase inicial de abertura do aulacógeno, foi tomado como objeto de teste da existência de evento deformacional mais antigo do que o encontrado nas unidades de cobertura.

Neste trabalho, descreve-se as rochas, o arcabouço estrutural do Complexo Lagoa Real e propõe-se um modelo de evolução tectônica para o mesmo.

\section{ARCABOUÇO GEOLÓGICO REGIONAL O} Cráton do São Francisco e a sua contraparte africana, o Cráton do Congo, constituem as porções poupadas das deformações brasilianas que teriam culminado com a formação do Supercontinente Gondwana (Alkmim \& Martins-Neto 2001, dentre outros). Em seu interior, o Aulacógeno do Paramirim (Pedrosa-Soares et al. 2001) representa uma importante descontinuidade, cujo arcabouço estrutural foi reativado durante sucessivos episódios formadores de bacia, desde o Paleo até o Neoproterozóico (Schobbenhaus 1996, Danderfer Fo 2000). Além disso, o aulacógeno serviu como importante canalizador das tensões originadas durante as colisões entre as placas São Francisco e Amazônia (Cruz 2004, Cruz \& Alkmim 2006). Tais colisões teriam provocado a inversão parcial do aulacógeno, cujo registro, no seu embasamento, pode ser observado a partir do paralelo $12^{\circ} 45^{\prime}$ (Danderfer Fo 2000, Cruz 2004). Como demonstrado por esses autores, a expressão da interação entre o Aulacógeno do Paramirim e o Orógeno Araçuaí Oeste Congo pode ser também encontrada nas unidades de preenchimento do aulacógeno, ou seja, nos supergrupos Espinhaço e São Francisco.

O substrato do Aulacógeno do Paramirim é constituído por um conjunto de gnaisses, migmatitos e seqüências vulcanossedimentares de idade arquena-paleoproterozóica (Marinho 1991, Basto-Leal et al. 1997, por exemplo). A cobertura está representada pelos supergrupos Espinhaço e São Francisco. O Supergrupo Espinhaço é constituído por uma seqüência de sedimentos terrígenos com contribuições de rochas vulcânicas na base. A sua deposição teria iniciada em 1,7 Ga (Brito Neves et al. 1980) com a colocação de rochas vulcânicas ácidas em regime trafrogênico. No topo, uma importante discordância erosiva o separa da unidade sotoposta, o Supergrupo São Francisco (Guimarães 1996). Esse supergrupo é constituído na base por sedimentos de origem glaciogênica que em direção ao topo passa gradualmente para um conjunto de rochas carbonáticas de idade máxima em torno de 0,7 Ga (Misi \& Veizer 1996).

AS ROCHAS DO COMPLEXO LAGOA REAL O mapeamento geológico da área de ocorrência do Complexo Lagoa Real (Figs. 3 e 4) permitiu individualizar meta-granitóides, granitóides milonitizados em graus variados, albititos, microclinitos, epidositos, piriclasitos (enclaves), anfibolitos e diabásios, que serão descritos 


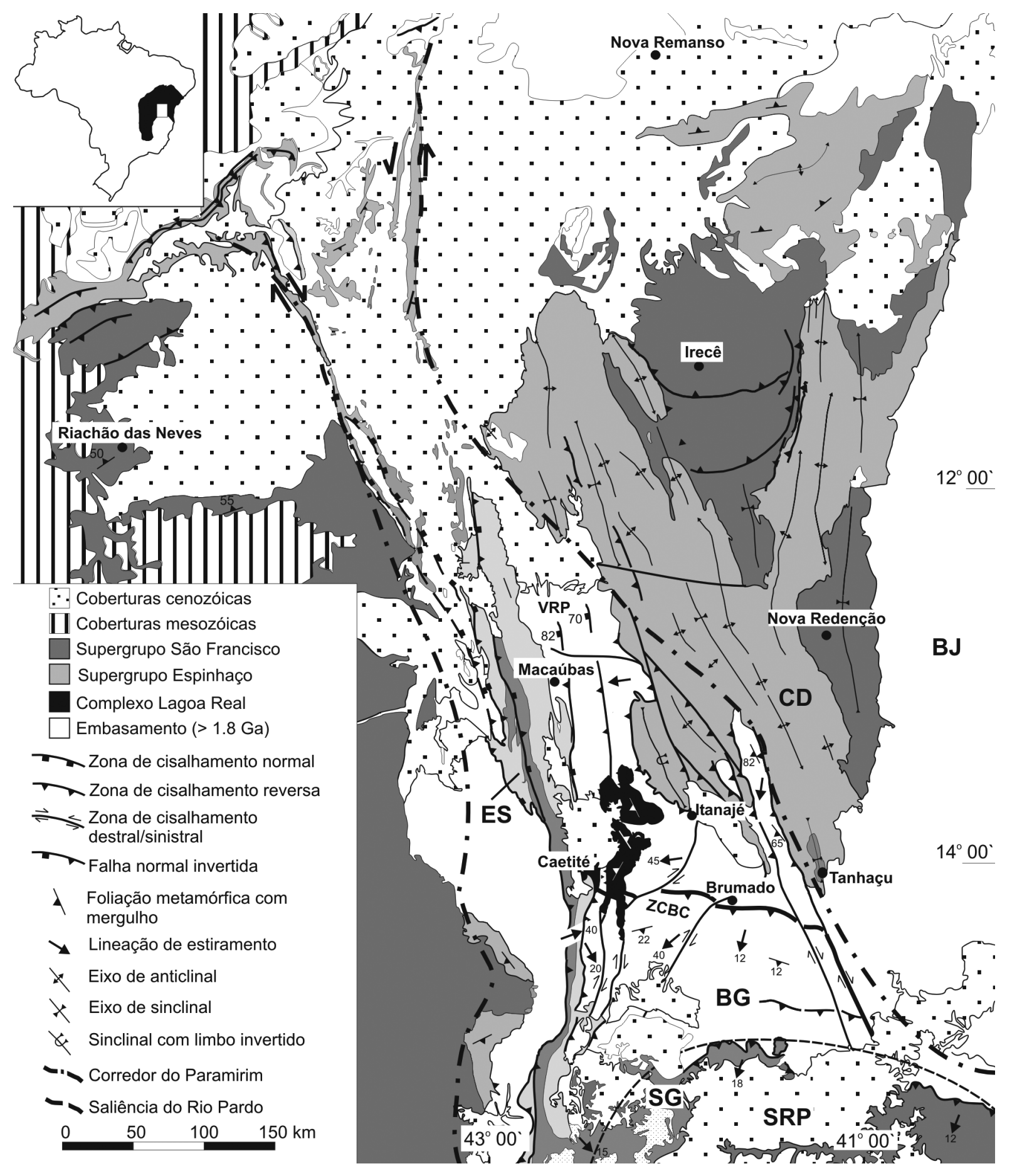

Figura 2 - Mapa Geológico simplificado do Aulacógeno do Paramirim, enfatizando as principais unidades geológicas e estruturas tectônicas de idade brasiliana. Mapa compilado a partir de Schobbenhaus et al. (1981) e Barbosa \& Dominguez (1996). Fonte: Cruz (2004).

a seguir. As rochas do Complexo Lagoa Real exibem uma foliação milonítica heterogeneamente desenvolvida, dando origem a um arranjo de meta-granitóides isotrópicos, que se alternam com faixas deformadas constituídas por granitóides milonitizados, gnaisses, albititos, microclinitos e epidositos.

Em função das suas características litológicas e estruturais, a área de ocorrência do complexo foi subdividida em três setores distintos, como mostrado na figura 5.

Metagranitóides Lagoa Real Compreendem ao conjunto de meta-granitóides genericamente denominados de granito São Timóteo por Fernandes et al. (1982). O meta-granitóide São Timóteo foi datado pelo método $\mathrm{U} / \mathrm{Pb}$ tendo-se obtido a idade de cristalização em torno de 1,7 Ga (Turpin et al. 1988, Cordani et al. 1992). A sua intrusão no embasamento cratônico seria resultante 


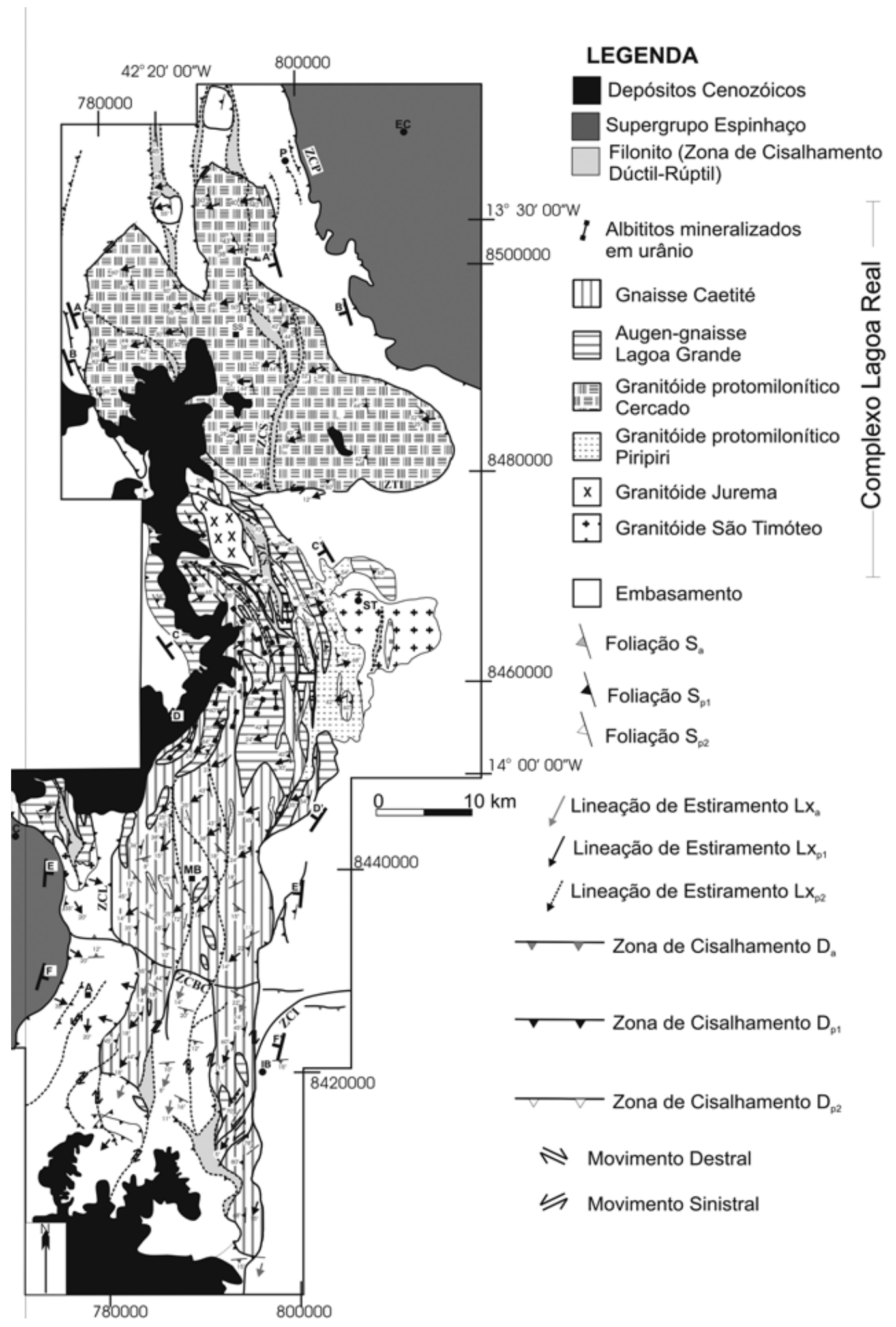

Figura 3 - Mapa Geológico do Complexo Lagoa Real. A localização dos perfis da Figura 4 é mostrada no mapa geológico.

do plutonismo associado à primeira fase rifte registrada no aulacógeno do Paramirim, que remonta a $1,7 \mathrm{Ga}$, ou seja, ao período Estateriano do final do Paleoproterozóico. De acordo com McReath et al. (1981) e Teixeira (2000), o magma que produziu o meta-granitóide São Timóteo é o mesmo que deu origem às metavulcânicas que correm na base do Supergrupo Espinhaço, a unidade mais velha do preenchimento do Aulacógeno do Paramirim.

Como será demonstrado a seguir, o que foi originalmente denominado de granito São Timóteo por Fernandes et al. (1982) trata-se de um conjunto de álca- 

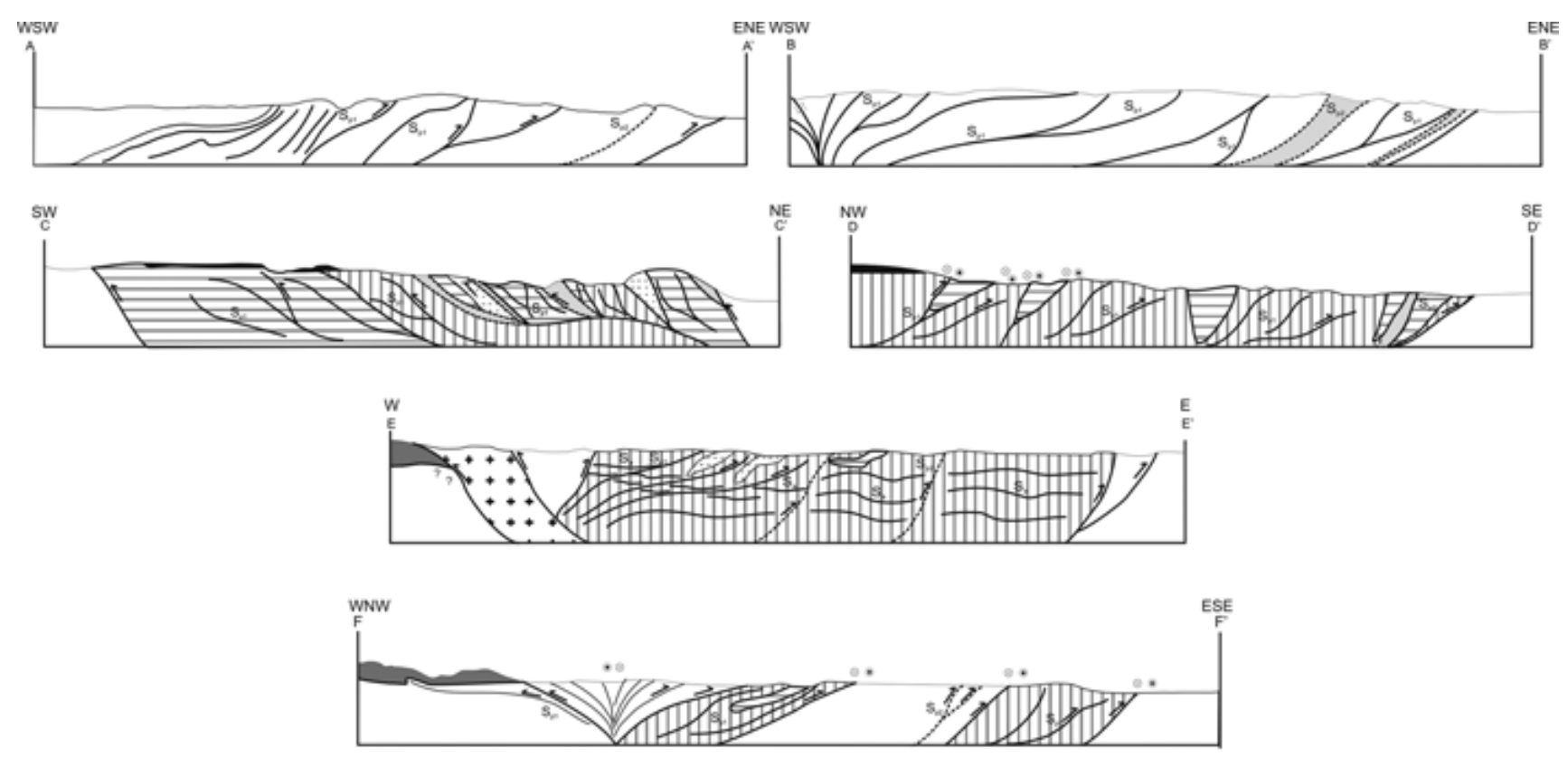

Figura 4 - Perfis geológicos no Complexo Lagoa Real. A localização dos perfis encontra-se na Figura 3. A legenda é a mesma da figura 3.

li-feldspato meta-granitos e meta-sienogranitos, cujas diferenças texturais permitem subdividí-lo em duas fácies distintas: uma porfirítica a cumulática, denominadas de meta-granitóide São Timóteo e outra fanerítica a porfirítica, denominada de meta-granitóide Jurema. As principais texturas magmáticas reliquiares observadas nessas rochas são holocristalina, subidiomórfica, porfirítica, marcadas pela presença de fenocristais de feldspato potássico; glomeroporfirítica a cumulática, essa última devido à acumulação de cristais de feldspato potássico (cúmulos), poiquilítica, com inclusões de biotita, zircão, titanita, anfibólio, plagioclásio e apatita, em feldspato potássico e plagioclásio; ou ainda de apatita e zircão em plagioclásio e biotita; e de alanita, zircão, apatita, ilmenita, magnetita e pirita, em biotita; de quartzo, apatita, ilmenita e magnetita em anfibólio, traquítica, pela orientação preferencial de feldspato potássico em rochas porfiríticas, e granofírica. Mimerquitas podem ser encontradas nessas rochas. Nessas rochas, a biotita é castanha. A mineralogia primária encontra-se parcialmente substituída por uma mineralogia de alteração metamórfica constituída por epidoto, biotita verde, clorita, mica branca e quartzo. Feições de deformação podem ser encontradas nessas rochas, mas a modificação da trama não ultrapassa $10 \%$ do volume total da rocha.

Os meta-granitóides São Timóteo e Jurema englobam um conjunto de rochas hololeucocráticas a leucocráticas, com coloração variando entre cinzarósea a cinza-azulada. A composição dessas rochas é também bastante variável, desde diorítica até granítica, passando por monzonítica, sienítica, sienogranítica, álcali-feldspato sienítica, quartzo-álcali feldspato sienítica e álcali-feldspato granítica. Os minerais varietais são biotita e anfibólio, podendo ocorrer ortopiroxênio e

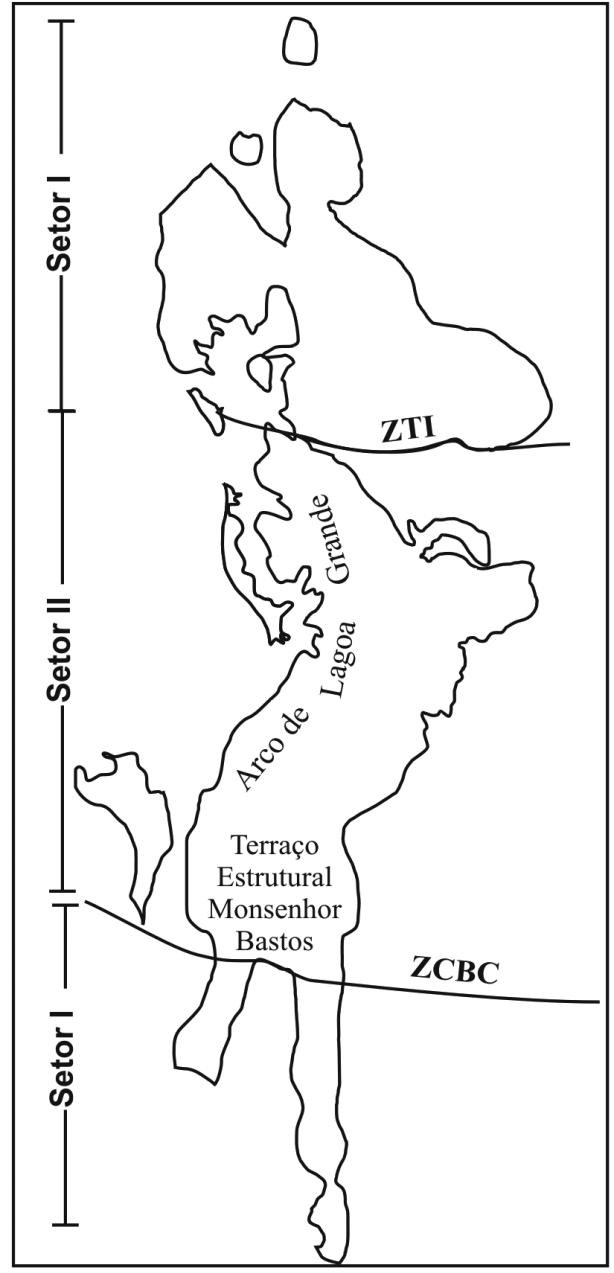

ZCP: Zona de cisalhamento Brumado Caetité. ZTI- Zona de Transferência de Itanajé.

Figura 5 - Domínios de estruturais do Complexo Lagoa Real. 
granada. A biotita e o anfibólio, juntos, não ultrapassam $20 \%$ do volume total da rocha.

Os meta-granitóides São Timóteo possuem fácies porfirítica e cumulática, com granulação grossa a muito grossa. Em afloramento, textura piterlítica pode ser encontrada. Ao microscópio, textura granofírica é comum. A fácies porfirítica é anisotrópica e predominam fenocristais de feldspato potássico. Esses fenocristais são subédricos a arredondados, e ovóides. Também podem ser encontrados fenocristais de plagioclásio. Os fenocristais variam de 3 a 12 (em média, em torno de 5 $\mathrm{cm})$. Apresentam orientação preferencial de fluxo magmático, conferindo à rocha uma foliação primária, com orientação dominante 235/33 (Fig. 6). A matriz possui granulação média a fina, isotrópica e nela estão: quartzo, feldspato potássico, plagioclásio, biotita e anfibólio. $\mathrm{Na}$ fácies cumulática, a trama primária é isotrópica. Os cumulatos são, principalmente, de feldspato potássico, com tamanho entre 1 e $5 \mathrm{~mm}$. A matriz intercúmulo possui composição semelhante a da fácies porfirítica.

Os meta-granitóides Jurema, por sua vez, possuem fácies porfirítica e granulação média. A fácies porfirítica é anisotrópica e apresenta fenocristais de feldspato potássico e de plagioclásio (até $2 \mathrm{~cm}$ de comprimento), arranjados em uma foliação de fluxo magmático. A matriz possui granulação média a fina, equigranular. É constituída por feldspato potássico, plagioclásio, quartzo, biotita, anfibólio e minerais acessórios, tais como zircão, apatita e titanita, cada um em proporções inferiores a $1 \%$.

\section{Granitóides milonitizados e Ortognaisses}

Em afloramento e em escala regional (Fig. 3), os granitóides do Complexo Lagoa Real apresentam variados graus de deformação, desde protomilonítos, milonitos até ultramilonitos, conforme a definição de Sibson (1977), que representam os produtos da deformação que marcou a inversão do Aulacógeno do Paramirim. Granitóides milonitizados foram datados por Cordani et al. (1992), tendo sido obtida idade $\mathrm{Pb} / \mathrm{Pb}$ (Rocha total) de $1706 \pm 107 \mathrm{Ma}$. Tal idade é semelhante ao que foi encontrado por Turpin et al. (1988) para os granitóides São Timóteo.

Em mapa e em afloramentos, essas rochas possuem formas alongadas e fusiformes, alternando-se com os meta-granitóides. As fácies foram denominadas de acordo com a localidade mais próxima de sua ocorrência. Dessa forma, foram discriminados os granitóides protomiloníticos Cercado, o augen-gnaisses Lagoa Grande (milonitos) e o gnaisse Caetité (ultramilonitos) (Figs. 3 e 7).

Existem diferenças significativas quanto aos processos deformacionais/metamórficos que envolvem o plagioclásio e o feldspato potássico, se forem considerados os setores de I a III de ocorrência do Complexo Lagoa Real (Fig. 5). No primeiro, predominam processos envolvendo a fragmentação e rotação friccional dos feldspatos. Os fragmentos de feldspato potássico são angulosos e possuem formas e tamanhos variados. A hidratação dos feldspatos, por outro lado, é um proces-

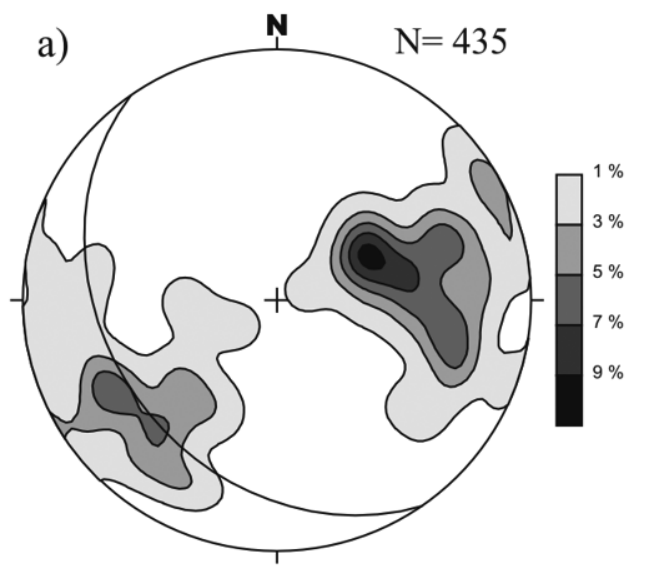

Foliação magmática - $\mathrm{S}$
Complexo Lagoa Real
Granitóide São Timóteo
Máximo: $235 / 33$

Figura 6 - Diagrama de projeção estereográfica (Hemisfério inferior) da foliação magmática dos meta-granitóides.

so pouco eficiente nesse setor, estando restrita às encaixantes de grandes zonas de cisalhamento dúctil-rúpteis que evoluíram para filonitização.

Por outro lado, em toda a região localizada nos setores II e III (Fig. 5), a deformação do plagioclásio e do feldspato potássico dá-se, preferencialmente, pela deformação por deslizamentos de discordâncias intracristalinas. Esses processos promovem ao desenvolvimento de extinção ondulante no quartzo e feldspatos. A recristalização sintectônica foi um mecanismo extensamente desenvolvido e formou novos grãos a partir de porfiroclastos daqueles minerais. Isso ocorre, preferencialmente, por meio da rotação de subgrãos, com a geração de estruturas núcleo-manto. Nas rochas menos deformadas ocorrem grãos poligonais formando estrutura do tipo núcleo-manto em torno dos porfiroclastos. Por outro lado, naquelas mais deformadas, os novos grãos aglomeram-se em níveis contínuos que progressivamente paralelizam-se com a foliação metamórfica. As microtexturas envolvendo feldspatos sugerem temperatura crescente de deformação, desde o setor I ate o setor IIl.

Nos granitos protomiloníticos e nos augengnaisses Lagoa Grande (milonitos), os porfiroclastos de feldspato potássico apresentam-se parcialmente transformados em albita por intermédio do desenvolvimento de pertitas metassomática em chama ou de manchas com geometrias diversas, desde amebóides a esqueléticas. A pertita metassomática distribui-se irregularmente nos porfiroclastos e está truncada pelos novos grãos poligonais produto da recristalização sintectônica. Os novos grãos recristalizados truncam as pertitas dos porfiroclastos e não estão albitizados. Tal textura sugere que a substituição do feldspato potássico pela albita é 
a

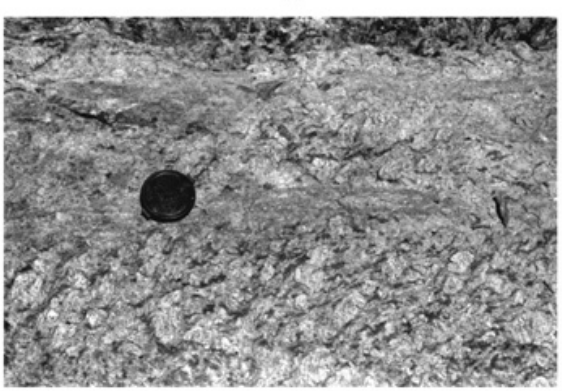

d

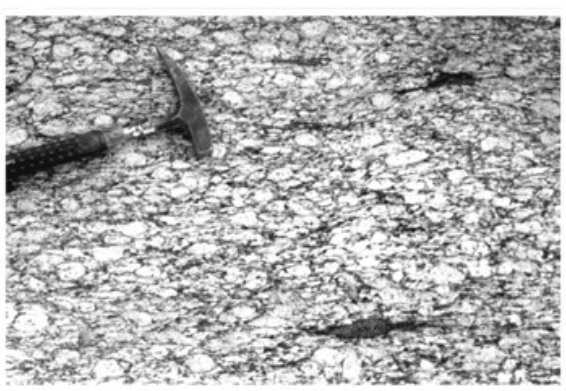

b

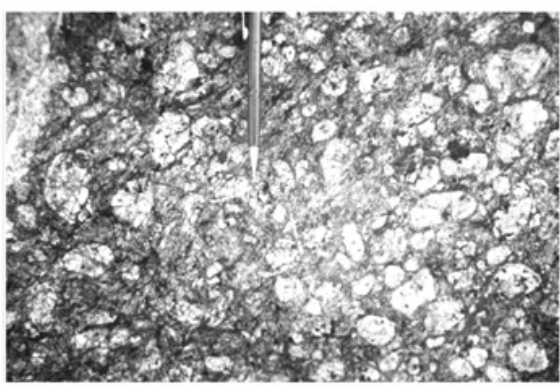

e

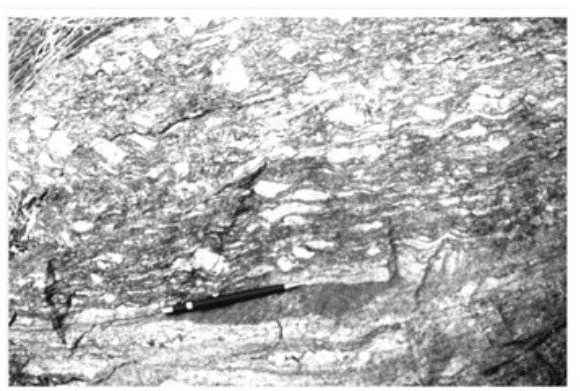

$\mathrm{C}$

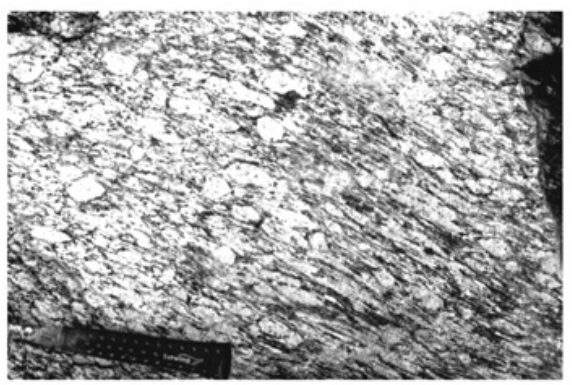

f

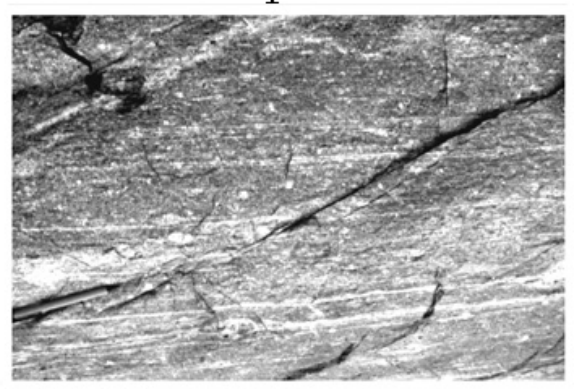

Figura 7 - Estágios de deformação do granitóide São Timóteo: a) meta-granitóide praticamente intacto; b) granitóide protomilonítico Piripiri; c) transição entre o granitóide protomilonítico Piripiri e o augen-gnaisse Lagoa Grande (milonitos); d) augen-gnaisse Lagoa Grande (milonitos); e) transição entre augen-gnaisse Lagoa Grande (milonitos) e gnaisse Caetité (ultramilonitos); f) gnaisse Caetité (ultramilonitos). A deformação cresce de a para $f$. As figuras $a, b, c, d$, f são vistas em planta e a figura e, em perfil.

anterior à deformação.

O plagioclásio ocorre como porfiroclastos, ou como inclusões e pertitas metamórficas em porfiroclastos de feldspato potássico, ou como grãos poligonais na matriz. Os porfiroclastos representam fenocristais relícticos do protólito ígneo e que foram poupados da deformação. Os grãos são subédricos a anédricos, tabulares e, ao microscópio, apresentam geminação albita.

O quartzo apresenta-se em cristais xenoblásticos, granulares, isolados ou formando bolsões e agregados lenticulares de grãos poligonais. Podem ocorrer na matriz ou como cristais intersticiais entre os feldspatos ou formando ribbons policristalinos, compondo o bandamento metamórfico. A extinção é moderada a fortemente ondulante. A deformação se dá por meio de processos dúcteis, envolvendo deslizamento de discordâncias. Nos domínios de menor deformação, a recristalização sin-deformacional ocorre, preferencialmente, por intermédio de mecanismos envolvendo migração de bordas de grãos. Os grãos orientados desfavoravelmente aos deslizamentos intracristalinos, isto é, com eixo-c em alto ângulo com a direção de compressão máxima, são progressivamente substituídos por grãos com eixo-c orientados em baixo ângulo com a direção de compressão máxima, por intermédio da migração de bordas de grãos. Entretanto, nos domínios de maior deformação, o principal mecanismo envolvido foi à rotação de subgrãos, denunciada pela semelhança entre a geometria e tamanho dos subgrãos e novos grãos. $\mathrm{O}$ padrão de distribuição dos eixos-c de quartzo estão apresentados na figura 8. À medida que se caminha para sul nota-se uma mudança do sistema de deslizamento, passando de paralelo ao plano basal $<a>$, para paralelo ao prisma $<\mathrm{c}>$. Tal distribuição sugere aumento de temperatura de deformação naquele sentido.

Os granitóides protomiloníticos Piripiri apresentam composição semelhante ao granitóide São Timóteo, ou seja, variável entre sienítica, álcali-feldspato sienítica, quartzo-álcali feldspato sienítica, álcali-feldspato granítica e sienogranítica.

Nessas rochas, texturas metamórficas e deformacionais coexistem com feições reliquiares do protólito ígneo. Com o aumento progressivo da deformação, transformam-se em augen-gnaisses Lagoa Grande (milonitos) e nos gnaisses Caetité (ultramilonitos). Em ambos os casos, texturas magmáticas foram totalmente substituídas pelas texturas deformacionais. Os gnaisses Caetité apresentam bandamento composicional contínuo, com largura centimétrica (máximo de 5 centímetros), marcado por proporções variáveis entre microclina, plagioclásio, biotita, magnetita e quartzo.

A foliação deformacional varia desde anastomosada, descontínua nos termos menos deformados (protomilonitos e milonitos), até contínua e paralelizada com o bandamento composicional nos termos mais deformados (ultramilonitos). São observadas estruturas $\mathrm{S} / \mathrm{C}$, sendo que o ângulo médio entre elas varia entre $30-40^{\circ}$ e $0-5^{\circ}$, em protomilonitos e ultramilonitos, respectivamente.

Diferenças significativas envolvem o granitóide 
Z

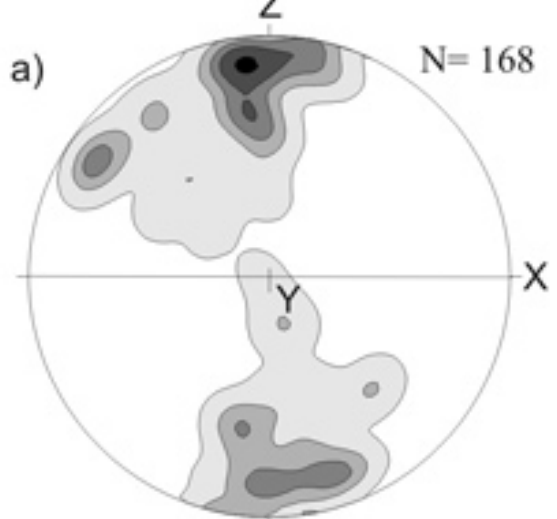

Amostra 995

Eixo-c de quartzo

Complexo Lagoa Real Setor I

Máximo: 353/13

\section{Z}

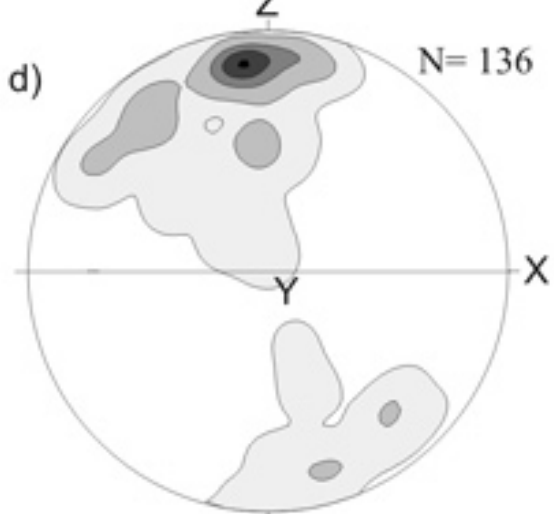

Amostra 699

Eixo-c de quartzo

Embasamento

Setor I

Máximo: 353/15

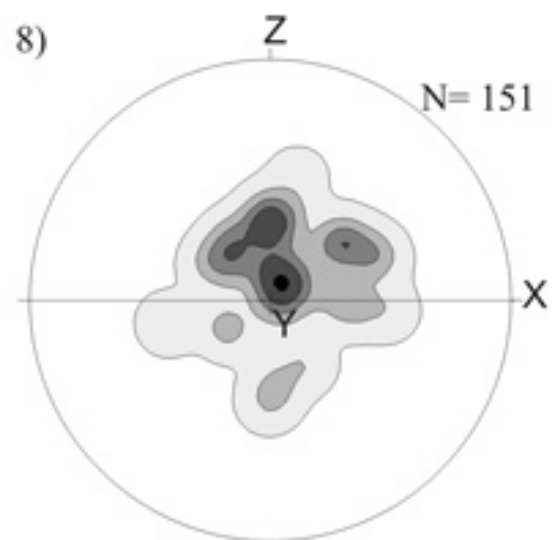

Amostra 444

Eixo-c de quartzo Complexo Lagoa Real Setor II

Máximo: 350/85

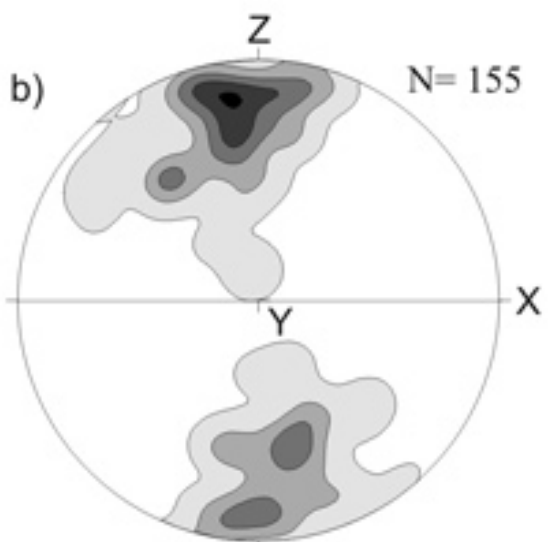

Amostra 852

Eixo-c de quartzo Complexo Lagoa Real Setor 1

Máximo: 352/16

Z

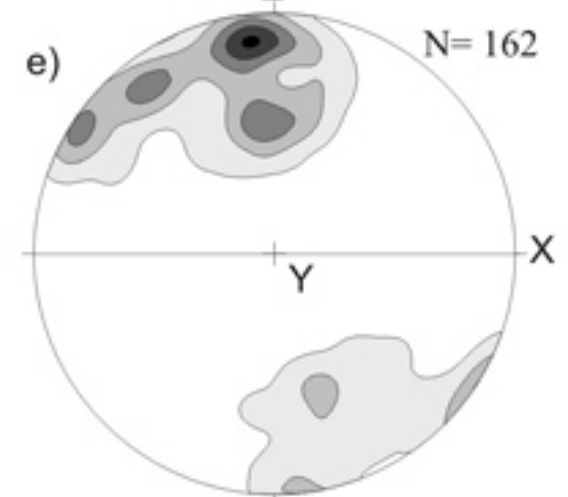

Amostra 1658

Eixo-c de quartzo Vulcânica Rio dos Remédios Setor I

Máximo: 353/12

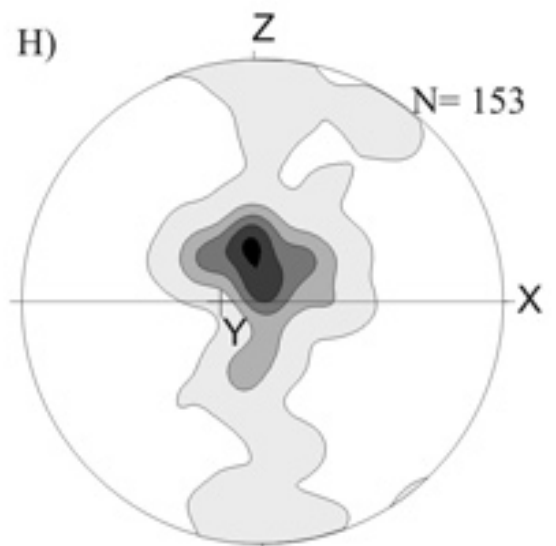

Amostra 280

Eixo-c de quartzo Complexo Lagoa Real Setor II

Máximo: $348 / 62$

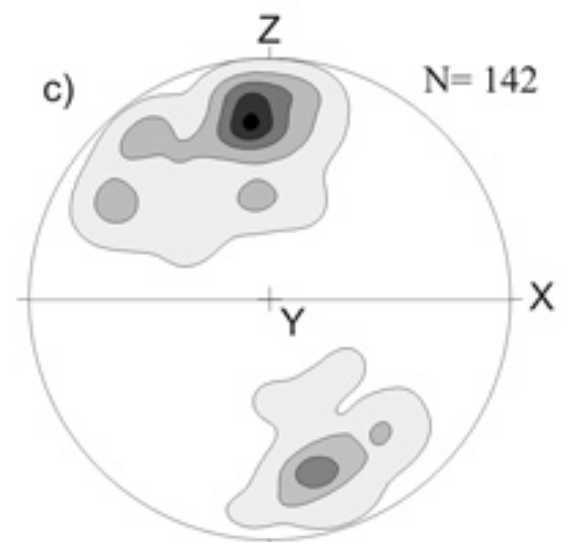

Amostra 700

Eixo-c de quartzo

Embasamento Setor 1

Máximo: 354/27

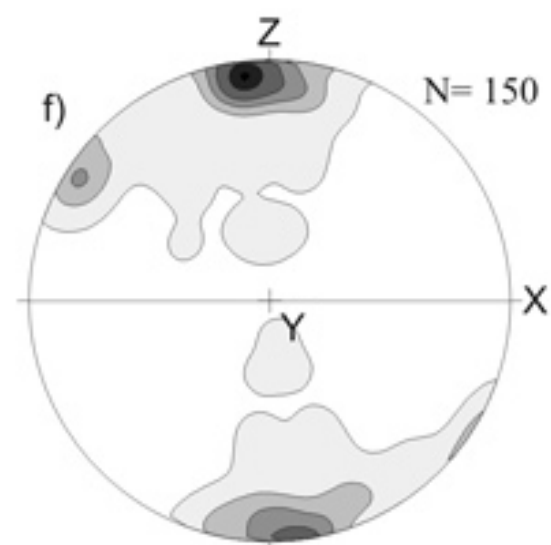

Amostra 028

Eixo-c de quartzo Vulcânica Rio dos Remédios Setor I

Máximo: 353/07

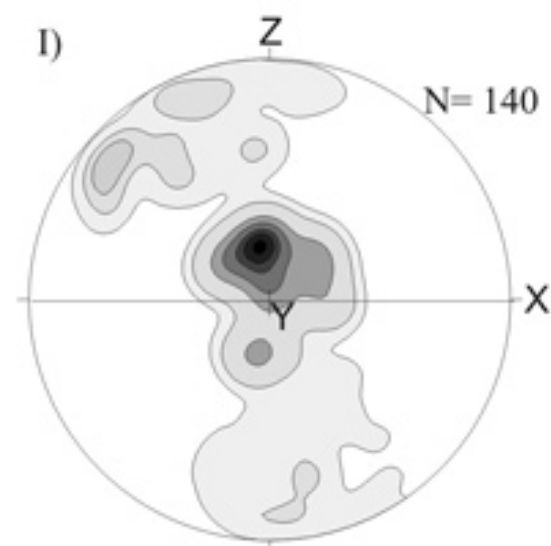

Amostra 554

Eixo-c de quartzo Complexo Lagoa Real Setor II

Máximo: $337 / 68$

Figura 8 - Tramas cristalográficas de eixo-c de quartzo determinadas nos tectonitos do compartimento I e II. $X$ e Z correspondem aos eixos do elipsóide de deformação finita. Os intervalos de contorno são iguais a 1, 2, $3,45 \%$ por $1 \%$ de área. 
milonítico Cercado com relação às demais rochas do complexo. Nesse caso, predomina textura cataclástica envolvendo os feldspatos. O bandamento deformacional é bem desenvolvido, sendo lenticular e descontínuo. Está marcado por níveis finamente espaçados com proporções variáveis de fragmentos de feldspato potássico e plagioclásio, grãos poligonais de quartzo e biotita verde. A foliação é anastomosada, descontínua e ocorre contornando os porfiroclastos de feldspato potássico, plagioclásio, bem como o bandamento metamórfico. São observadas estruturas $\mathrm{S} / \mathrm{C}$, sendo que o ângulo médio entre elas varia entre $20-25^{\circ}$.

Albititos Como mencionado anteriormente, existe uma nítida associação entre albititos e microclinitos com os meta-granitóides e gnaisses do Complexo Lagoa Real. Tal associação repete-se em todas as escalas. Datações U/Pb (zircão) obtidas em albititos do complexo em questão por Pimentel et al. (1994) mostram que os granitóides São Timóteo são possíveis protólitos dessas rochas.

Os albititos apresentam coloração cinza-esbranquiçada e aspecto sacaroidal. Como são os principais hospedeiros da mineralização de urânio, foram amplamente estudados por diversos autores, como: Sobrinho et al. (1980), Costa et al. (1985), Raposo \& Matos (1982), Lobato (1985), Brito et al. (1984), Ribeiro et al. (1984), Maruèjol et al. (1987), Lobato \& Fyfe (1990), dentre outros.

Prates \& Fuzikawa (1984) classificaram como albititos as rochas com porcentagem de albita superior a $70 \%$. Essa foi a classificação aqui adotada. As rochas com volume de albita inferior a $70 \%$ foram agrupadas nas diversas categorias de gnaisses, aqui descritas anteriormente. Foram designadas de acordo com a abundância de minerais varietais na seguinte forma: pargasita/ hastingsita albitito, aegirina-augita albitito, magnetita- hematita albitito, siderofilita albitito, andradita-grossularita albitito e variações entre esses termos.

As rochas albitíticas formam corpos lenticulares, fusiformes, descontínuos, de largura e comprimento variáveis, desde milimétricos até centenas de metros. Podem atingir extensão de até 480 metros, largura de 30 metros e profundidade máxima de 850 metros (Ribeiro et al. 1984). O contato dessas rochas com as suas encaixantes é brusco ou gradacional, predominando o primeiro tipo.

Os corpos de albititos encontram-se paralelizados com a foliação impressa nos gnaisses Lagoa Real. Os albititos muitas vezes estão estirados e boudinados (Fig. 9). Nas regiões de máximo estiramento dos corpos, há a geração de dobras sobre a foliação das rochas encaixantes dos albititos, cujas charneiras são ortogonais à lineação de estiramento mineral (Fig. 9).

Os albititos possuem granulometria fina a grossa. As texturas comumente observadas são inequigranular, porfiroclástica, granoblástica poligonal e nematoblástica, marcada pela orientação do anfibólio e do piroxênio. Aparece ainda textura lepidoblástica, marcada pela orientação da biotita. Os minerais acessórios comuns são: microclina, quartzo, biotita, granada, anfibólio, magnetita, hematita, titanita, epidoto e calcita. Os máficos, geralmente, formam aglomerados lenticulares. São encontrados porfiroclastos de feldspato alcalino e plagioclásio apresentando textura ocelar e núcleo-manto.

Microclinitos Foram classificadas como microclinitos as rochas com porcentagem de microclina superior a 70\%. Essas rochas possuem coloração rósea a cremerosada e estão associados com os albititos. Formam corpos descontínuos com geometria fusiforme, da mesma forma que os albititos descritos anteriormente, e podem estar boudinados. $\mathrm{O}$ contato com as encaixantes

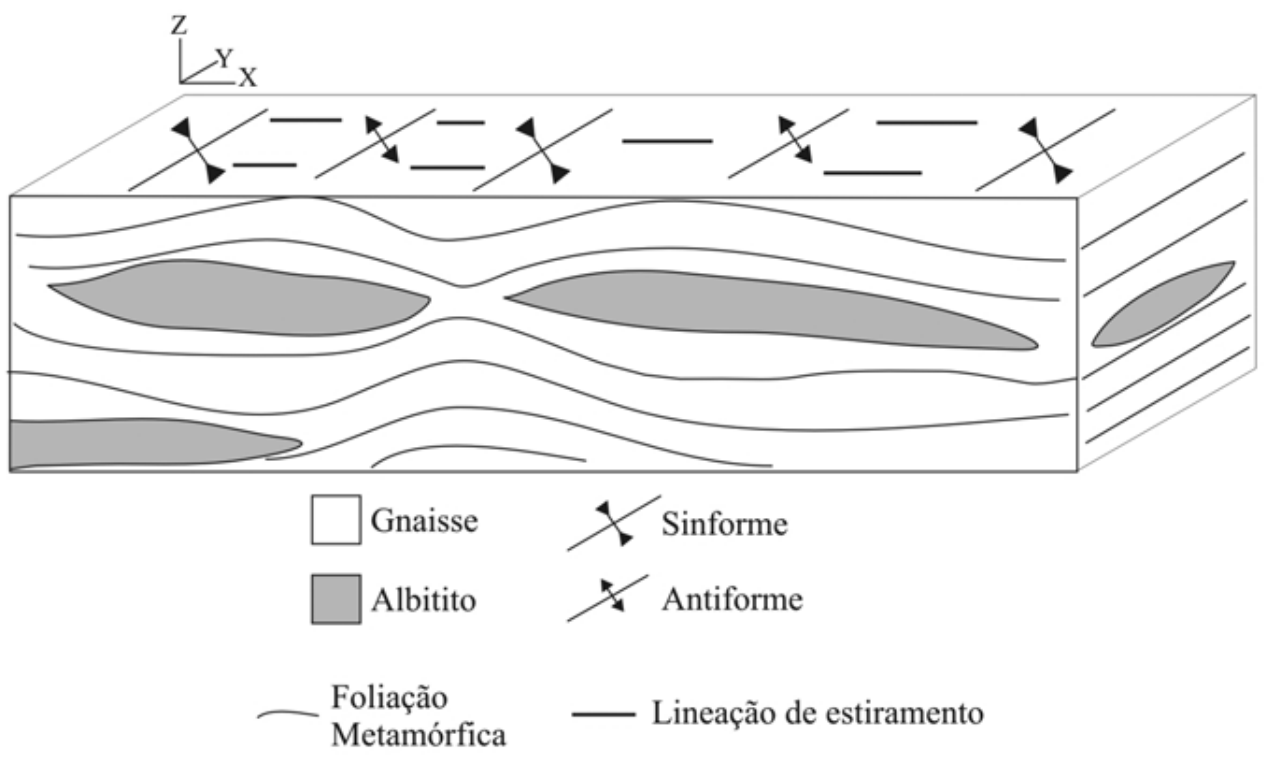

Figura 9 - Bloco-diagrama esquemático dos boudins envolvendo albititos. 
é abrupto. Freqüentemente observam-se intercalações entre os microclinitos, albititos, epidositos e granitóides protomiloníticos, augen-gnaisses e gnaisses, sugerindo relações genéticas entre eles. A largura dos corpos varia desde alguns centímetros até métricas (2 metros). São rochas com granulometria média a grossa e as texturas observadas são inequigranular, granoblástica poligonal e núcleo-manto.

Epidositos Os epidositos são verdes a verde-amarelados, possuem mais que $70 \%$ de epidoto na sua constituição e ocorrem associados com zonas de cisalhamento distensionais.

Enclaves e xenólitos Gnaisses e migmatitos de composição TTG, anfibolitos, piroxenitos, diabásios, biotita xistos e piriclasitos podem ser encontrados como enclaves nos granitos e gnaisses. Esses corpos apresentam dimensões variáveis entre centimétricas a métricas (máximo 2 metros), com formas desde retangulares a semelhante a fusos. De uma maneira geral, não são cartografáveis na escala de trabalho adotada. A exceção do piriclasito, as relações de contato entre essas rochas e suas encaixantes são, freqüentemente, visualizadas e típicas de xenólitos. No piriclasito, entretanto, a relação com as encaixantes não pôde ser observada em função da presença de coberturas recentes.

Nos gnaisses, os xenólitos ocorrem estirados em graus variáveis e são paralelizados à foliação principal.

O piriclasito, com coloração castanho-esverdeada, ocorre na porção central do Complexo Lagoa Real, próximo à cidade de São Timóteo. Trata-se de uma associação de gabronoritos, noritos e monzonoritos que, como demonstrado por Cordani et al. (1992), não são cogenéticos com as fácies graníticas do Complexo Lagoa Real. Essa rocha apresenta a seguinte composição modal: feldspato potássico (5-10\%), plagioclásio (70$80 \%$ ), piroxênio $(5-15 \%)$, biotita $(8-10 \%)$.

Anfibolitos Formam corpos tabulares, de largura extremamente variável, desde 30 centímetros até 25 metros. Em termos modais, hornblenda, biotita e plagioclásio ocupam 45 a $55 \%, 5$ a $15 \%$ e 25 a $45 \%$ do volume da rocha, respectivamente. São mesocráticos, de coloração verde escura a preto-esverdeada e granulometria média. Possuem textura equigranular, nematoblástica, marcada pela orientação da hornblenda, e anisotrópica.

Os anfibolitos exibem foliação metamórfica bem desenvolvida, marcada pela orientação planar da hornblenda.

Diabásio É mesocrático, com coloração preto-esverdeada a verde escura, e ocorre em corpos tabulares, descontínuos, com espessura máxima de 12 metros. É constituído por plagioclásio (45-60\%), hornblenda (15$35 \%)$, biotita $(5-12 \%)$ e augita $(0-5 \%)$. Possui granulometria fina a média e texturas holocristalina, equigranular, isotrópica e ofítica. Apresenta-se truncando ou sendo truncado pela foliação presente nas encaixantes. Possui orientação NNE/SSW e WSW-ESSE.

\section{ACERVO ESTRUTURAL E METAMORFISMO} NO COMPLEXO LAGOA REAL No Complexo Lagoa Real foram reconhecidas por Cruz (2004) e Cruz \& Alkmim (2006) duas famílias de estruturas deformacionais que estão relacionadas com dois campos

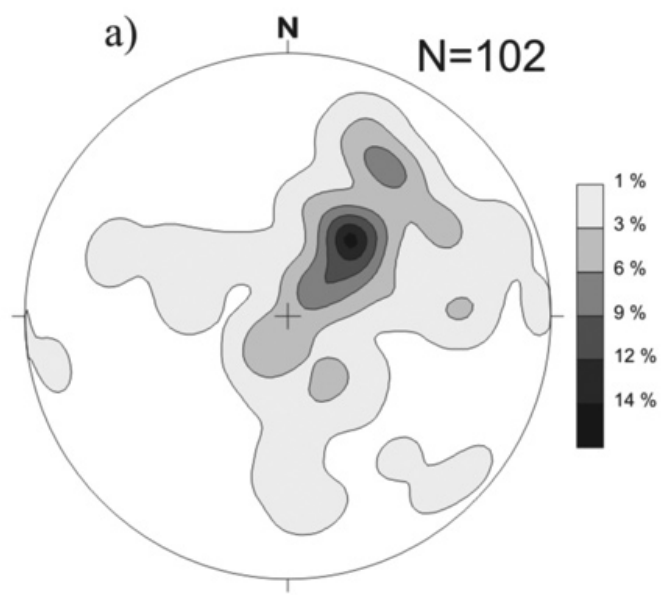

Foliação metamorfica - $\mathrm{S}_{\mathrm{a}}$ Zona de cisalhamento Brumado-Caetité Máximo: 220/30

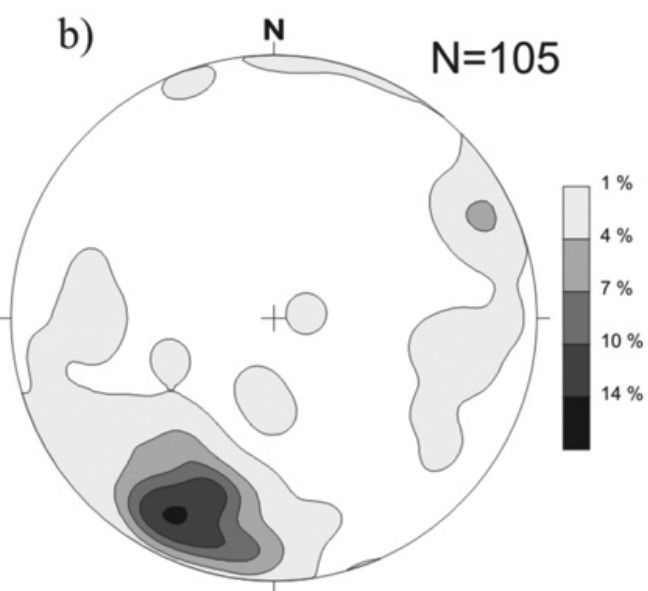

Lineação de estiramento - $L x_{a}$ Zona de cisalhamento Brumado-Caetité Máximo: 205/18

Figura 10 - Diagramas de projeção estereográfica (Hemisfério inferior) dos pólos da foliação e da lineação de estiramento da zona de cisalhamento Brumado-Caetité. N: número de medidas. 
cinemáticos distintos. A primeira, compressional, que compreende as fase $\mathrm{Da}$ e $\mathrm{Dp}$, e a segunda distensional, marcada pela fase De.

As estruturas compressionais compreendem o principal conjunto de estruturas deformacionais e foi responsável pela disposição espacial atual das unidades que compõem esse complexo. Ela envolve duas fases de deformação distintas, denominadas por aqueles autores de $D_{a}$ e $D_{p}$. A fase $D_{a}$, com topo estrutural para norte marcado por estruturas $S / C$, é responsável pela nucleação de zonas de cisalhamento com orientação WNWESSE, cujo principal registro é a zona de cisalhamento Brumado-Caetité. A foliação metamórfica e a lineação de estiramento associadas com essa fase de deformação orientam-se segundo 220/30 e 205/18, respectivamente (Fig. 10). A associação mineralógica a ela relacionada é marcada pela biotita (siderofilita), anfibólio (hastingsita/pargasita), feldspato potássico, plagioclásio e quartzo, sugerindo condições mínimas de metamorfismo de fácies anfibolito.

A segunda fase, $\mathrm{D}$, trunca as estruturas anteriores e é responsável pelo desenvolvimento de zonas de cisalhamento. Subdivide-se nos estágios $\mathrm{D}_{\mathrm{p} 1}$ e $\mathrm{D}_{\mathrm{p} 2}$. No $\mathrm{D}_{\mathrm{p} 1}$, formaram-se zonas de cisalhamento que estruturaram os gnaisses, albititos e microclinitos. Associada a essas zonas, desenvolveu-se uma foliação deformacional/metamórfica $\left(\mathrm{S}_{\mathrm{p} 1}\right)$, heterogeneamente distribuída nas rochas do complexo. Essa estrutura varia de anastomosada, nas porções menos deformadas, a planar e contínua nas regiões em que a deformação foi mais intensa. O seu desenvolvimento está intimamente relacionado com a formação de um bandamento metamórfico marcado por alternância de níveis com hastingsita/pargasita, hedembergita/aegirina augita, andradita/grossularita, biotita, magnetita/hematita, e níveis com quartzo, albita e microclina. Por várias vezes, essas estruturas ocorrem subparalelas. Os indicadores cinemáticos recuperados nessas zonas são as estruturas $\mathrm{S} / \mathrm{C}$, dobras assimétricas e distribuição assimétrica do eixo-c do quartzo.

Nas rochas gnáissicas são reconhecidas dobras isoclinais envolvendo o bandamento metamórfico. Tais dobras são observadas nas escala meso e microscópicas e podem aparecer redobradas. A foliação plano axial, nesse caso, é paralela à foliação $\mathrm{S}_{\mathrm{pl}}$.

A foliação metamórfica associada à fase $\mathrm{D}_{\mathrm{p} 1} \mathrm{de}-$ lineia uma estrutura aproximadamente helicoidal (Fig. 11), já citada por diversos autores (dentre outros, Brito et al. 1984, Sobrinho et al. 1980, Raposo et al. 1984, Ribeiro et al. 1984). Embora o mergulho dessa superfície seja ora para SW, ora para NE, a sua direção NNW/ SSE, de uma maneira geral, é mantida. A lineação de estiramento, por outro lado, muda sua orientação. O setor I é marcado por movimentos frontais, reversos com transporte tectônico de WSW para ENE (Fig. 3). Os indicadores cinemáticos em todas as escalas de observação atestam o movimento reverso. A foliação $S_{p}$ apresenta-se em 257/41e a lineação de estiramento $\mathrm{Lx}_{\mathrm{pl}}^{\mathrm{p} 1}$ é de alta obliqüidade e posicionada em 255/40 (Figs. $12 \mathrm{a}, \mathrm{b})$.

O limite norte do Complexo Lagoa Real com os gnaisses do embasamento se faz por meio de zonas de cisalhamento com orientação NNW (Figs. 3 e 4, perfis A-A' e B-B'). O seu contato oeste é balizado pela zona de cisalhamento Licínio de Almeida e a leste pela zona de cisalhamento São Timóteo.

O setor II é marcado pela presença de duas importantes estruturas, o Arco de Lagoa Grande e o terraço estrutural de Monsenhor Bastos (Figs. 3 e 4, perfis C-C', D-D' e E-E'). Na porção nordeste do Arco de Lagoa Grande, a foliação metamórfica $\mathrm{S}_{\mathrm{p} 1}$ e a lineação de estiramento dispõem-se em 042/60 e 057/54, respectivamente (Figs. 12c, d). Na porção central dessa estrutura, a foliação orienta-se segundo $263 / 58$ e a lineação, com alta obliqüidade, posiciona-se em 248/40 (Figs. 12e, f). Na porção sudeste, $S_{p 1}$ possui atitude modal em torno de 281/61 e a lineaçấo de estiramento apresenta-se em 249/53 (Figs. 12g, h). Nas porções nordeste, central e sudoeste do arco em questão os movimentos são reverso, dextral e dextral reversa, respectivamente.

No Arco de Lagoa Grande observa-se uma série de falhas de transferência com orientação preferencial 193/76 (Figs. 3 e 13a). Uma dessas falhas, a zona de transferência de Itanajé, materializa o limite norte desse domínio. Essas zonas de cisalhamento foram nucleadas para acomodar a variação no ângulo de mergulho das estruturas no arco em questão, ao longo do qual se observa uma importante torção da foliação. A lineação de estiramento associadas a essas zonas é de baixa obliqüidade e orienta-se segundo 242/10 (Fig. 13b). O movimento é sinistral a sinistral reverso.

Fora dos limites do Arco de Lagoa Grande, entre as cidades de Caetité e Monsenhor Bastos, o bloco dos gnaisses da infra-estrutura isola dois compartimentos distintos por meio de uma estrutura pop-up que coloca um fragmento do embasamento sobre os gnaisses Lagoa Real (Fig. 4, Perfil E-E').

$\mathrm{Na}$ região de Monsenhor Bastos, a foliação metamórfica estrutura uma rampa subhorizontal, com a foliação principal mergulhando para todas as direções, mas, preferencialmente, a sua orientação é $235 / 20$ (Figs. 3 e 13c, d). No diagrama estereográfico, da figura 13c, observa-se uma geometria cônica da foliação que, em afloramento, lembra figura de interferência do tipo domos e bacias (Fig. 11). A lineação de estiramento posiciona-se em 239/08. A presença da zona de cisalhamento Brumado-Caetité, a sul da cidade de Monsenhor Bastos, permite supor que o terraço estrutural homônimo representa uma feição de interferência entre as estruturas $\mathrm{D}_{\mathrm{a}}$ e $\mathrm{D}_{\mathrm{p} 1}$.

No setor II, o contato oeste do Complexo Lagoa Real com os gnaisses do embasamento está recoberto pelas unidades terrígenas. O seu limite oeste é feito pela zona de cisalhamento Licínio de Almeida e o leste pela zona de cisalhamento São Timóteo (Fig. 3).

O setor III é dominado por transcorrências destrais orientadas, preferencialmente, na direção NNW e, subordinadamente, a NNE (Fig. 3). Nesse setor, a foliação $S_{p 1}$ tem orientação 254/45 e a lineação de estiramento $\mathrm{Lx}_{\mathrm{pl}}$ é de baixa obliqüidade e posiciona-se em 


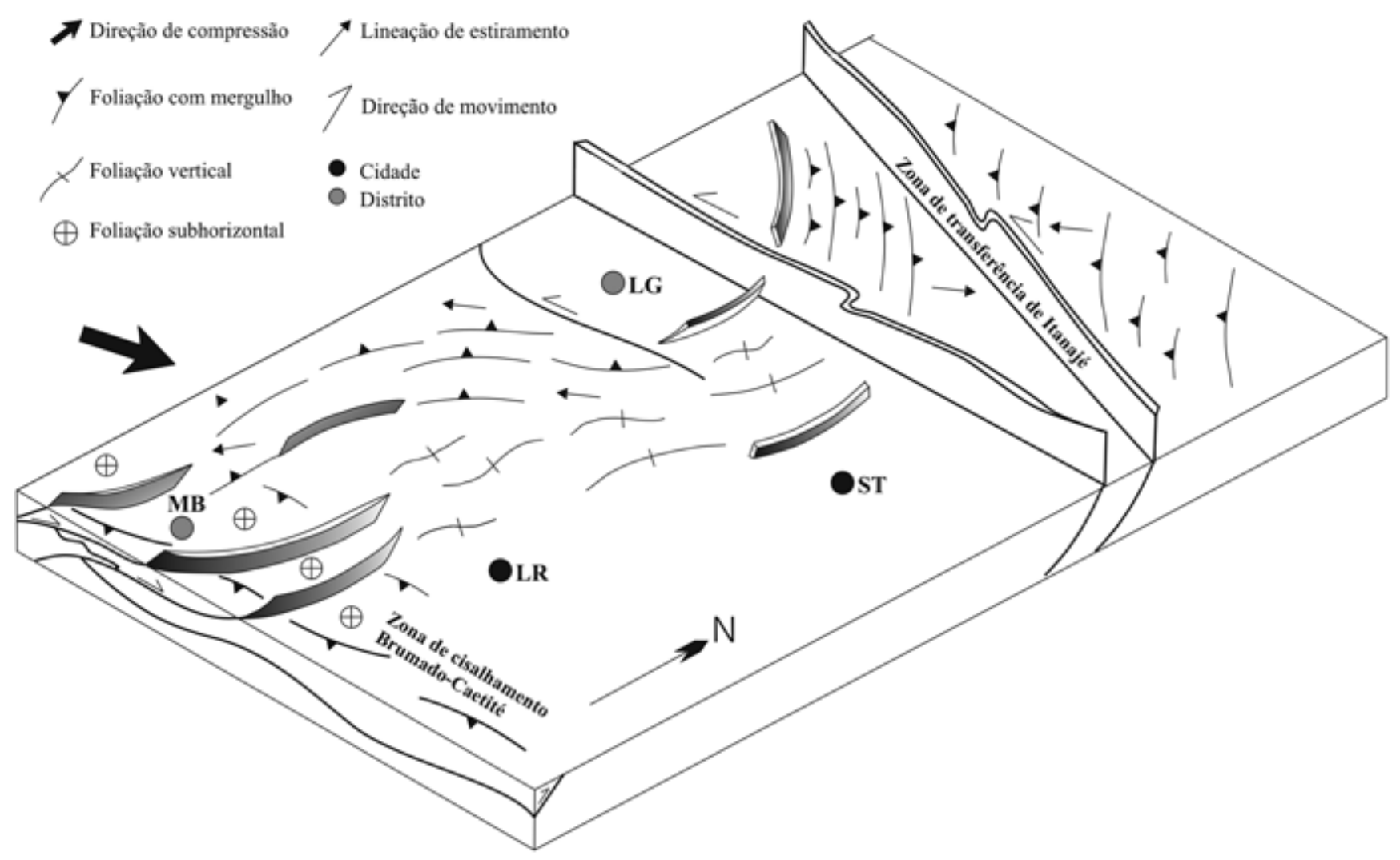

Figura 11 - Bloco diagrama mostrando o Arco de Lagoa Grande, no setor II da área de ocorrência do Complexo Lagoa Real. ST- São Timóteo, LR-Lagoa Real, LG-Lagoa Grande, MB-Monsenhor Bastos (Acabajá).

\section{8/14 (Figs. 13e, f).}

No limite oeste do complexo, a zona de cisalhamento de Licínio de Almeida articula-se com um conjunto de zonas de cisalhamento sinistrais reversas nucleadas nos gnaisses do embasamento (Fig. 3). A estruturação local é centrífuga, semelhante a uma flor positiva, que envolve os gnaisses do embasamento, as rochas do Complexo Lagoa Real, a leste, e os metassedimentos do Supergrupo Espinhaço, a oeste. No Complexo Lagoa Real, a deformação é acomodada por intermédio do desenvolvimento de movimentos reversos na zona de cisalhamento Licínio de Almeida, cuja orientação preferencial 250/40. A lineação de estiramento é de alta obliqüidade e o movimento associado a essa zona é para leste (Fig. 4, perfil F-F').

A leste, a zona de cisalhamento São Timóteo apresenta orientação preferencial e lineação de estiramento dispostas a $240 / 55$ e $210 / 22$, respectivamente. O movimento principal é dextral reverso.

Em seu extremo sul, o Complexo Lagoa Real também faz contato com os gnaisses da infra-estrutura (Fig. 3). Esse contato está parcialmente recoberto por depósitos arenosos recentes. Entretanto, quando exposto, ele se faz por meio de zonas de cisalhamento com orientação preferencial segundo WNW e lineação de estiramento, aproximadamente, NS. Os movimentos são reversos com vergência para norte. Essas estruturas colocam gnaisses da infra-estrutura sobre o Complexo
Lagoa Real e são truncadas pela foliação $\mathrm{S}_{\mathrm{p} 1}$ e $\mathrm{S}_{\mathrm{p} 2}$.

Associadas com a fase deformacional $\mathrm{D}_{\mathrm{p} 1}^{\mathrm{p} 1}$ foram observadas duas paragêneses minerais progressivas. A primeira constituída por quartzo, albita, anfibólio (hastingsita/pargasita), microclina, biotita (siderofilita) e plagioclásio, e a segunda por albita, microclina, piroxênio (hedembergita/aegirina augita) e granada (andradita/grossularita). A segunda paragênese e preferencialmente encontrada nos domínios de maior deformação.

São encontradas nas rochas do Complexo Lagoa Real zonas e fraturas de cisalhamento rúptil-dúcteis, com desenvolvimento de filonitos. Essas estruturas foram nucleadas durante o estágio $\mathrm{D}_{\mathrm{p} 2}$ e são responsáveis pelas reações retrometamórficas envolvendo plagioclásio, anfibólios, piroxênios e granada do Complexo Lagoa Real. Tais zonas de cisalhamento distribuem-se heterogeneamente e aproveitaram as zonas de cisalhamento nucleadas na etapa $D_{p 1}$ chegando a atingir $500 \mathrm{~m}$ de largura. As zonas de cisalhamento dúctil-rúpteis apresentam orientação semelhante à da foliação metamórfica $\mathrm{S}_{\mathrm{p} 1}$ encontrada em suas encaixantes. A foliação metamórfica associada a essas zonas apresenta-se, em geral, segundo 246/33, 059/63 e 256/51, nos setores I, II e III, respectivamente (Figs. 14a, c, e). A lineação de estiramento orienta-se segundo 247/29, 056/59 e 220/30 (Figs. 14b, d, f) e os movimentos são dirigidos para ENE, WSW e ENE, respectivamente.

No interior das zonas de cisalhamento dúctil-rú- 
a)
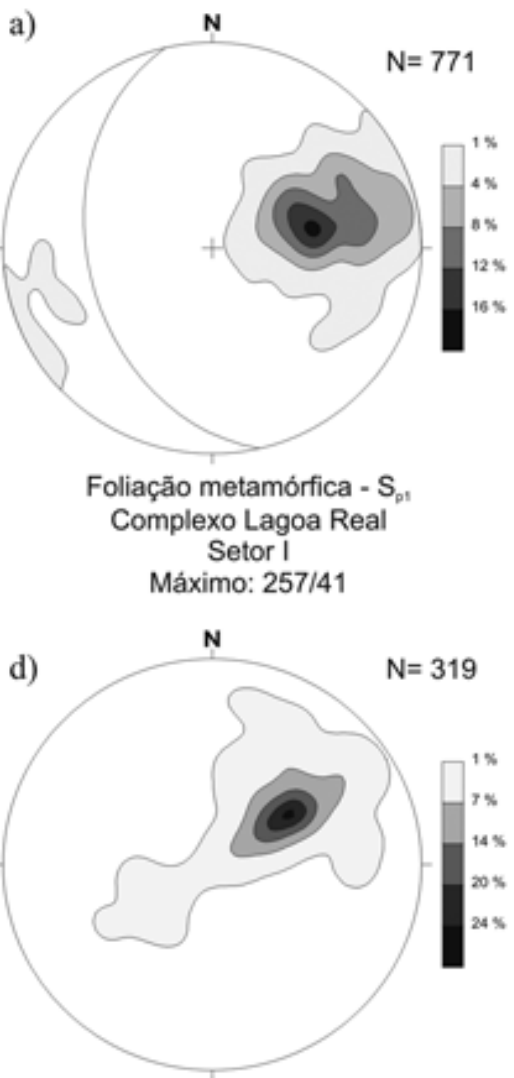

Lineação de estiramento - $\mathrm{Lx}$ Complexo Lagoa Real Setor II - Arco Lagoa Grande Setor nordeste Máximo: 057/54 b)

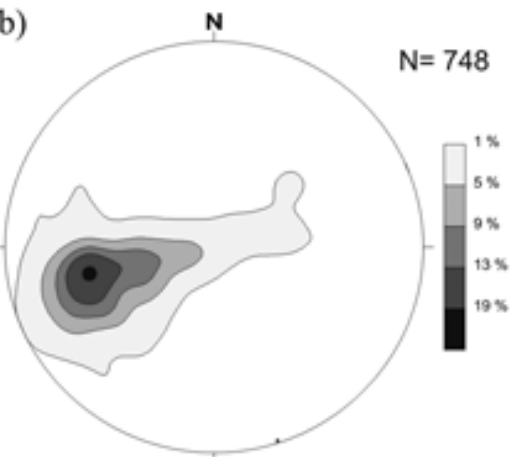
Lineação de estiramento - $L x_{p}$ Complexo Lagoa Real Setor I
Máximo: $255 / 40$

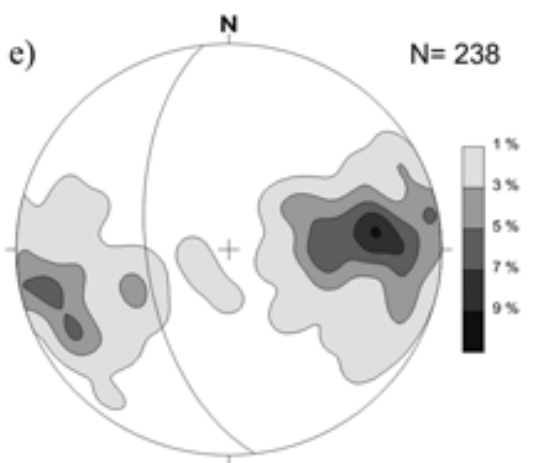

Foliação metamórfica - $S_{p}$ Complexo Lagoa Real Setor II - Arco Lagoa Grande Setor central Máximo: 263/58 c)

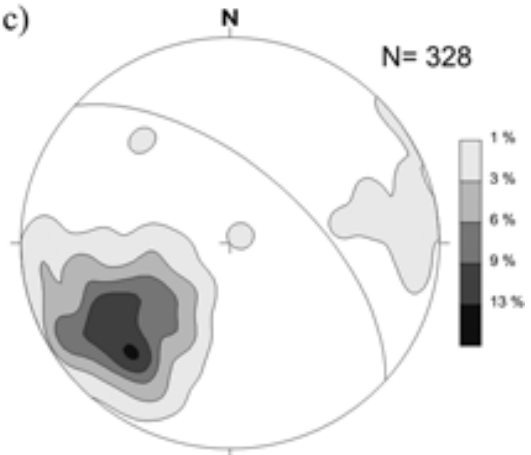

Foliação metamórfica - $\mathrm{S}_{\mathrm{p}}$ Complexo Lagoa Real Setor II - Arco Lagoa Grande Setor nordeste Máximo: 042/60

f) $\mathrm{N}$

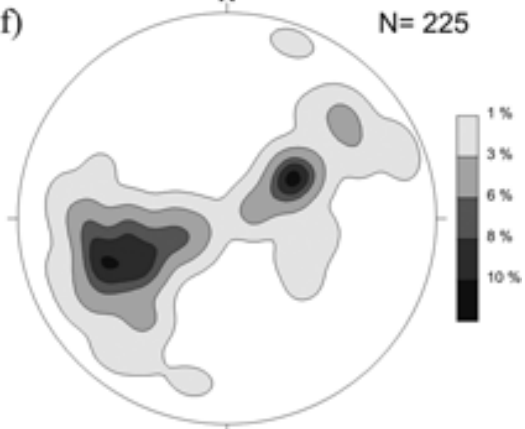

Lineaçăo de estiramento - $L x_{p}$ Complexo Lagoa Real

Setor II - Arco Lagoa Grande Setor central

Máximo: 059/57 // 248/40
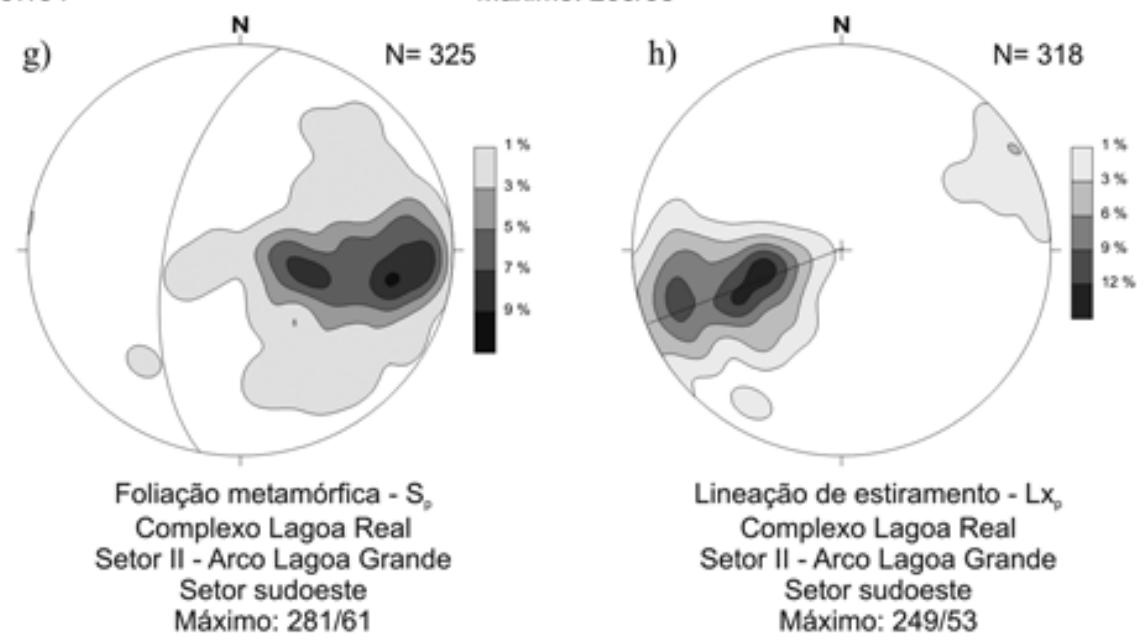

Figura 12 - Diagramas de projeção estereográfica (Hemisfério inferior) dos pólos da foliação metamórfica $S_{p l}$ e da lineação de estiramento Lxp nos setores I e II.

pteis ocorrem protomilonitos, milonitos e filonitos, predominando os últimos. Ultramilonitos, de acordo com o conceito de Sibson (1977), não foram observados. O contato dos tectonitos com as encaixantes é brusco. Associada à variação textural, são observadas importantes modificações mineralógicas. Nota-se, de uma maneira geral, das regiões menos deformadas para as mais deformadas, um aumento progressivo no conteúdo de filossilicatos e uma diminuição no volume de quartzo, com desaparecimento de plagioclásio, feldspato potássico, anfibólio e piroxênio. Os minerais opacos concentram-se na matriz e formam níveis individualizados.

A paragenese metamórfica associada com a fase $\mathrm{D}_{\mathrm{p} 2}$ é regressiva e marcada pela biotita verde, quartzo, mica branca e clorita. Essa paragênese é encontrada nos meta-granitóides e nos termos mais deformados.

Uma família de estruturas associa-se com a fase distensional $D_{e}$ e envolve fraturas e zonas de cisalhamento dúctil-rúpteis a dúcteis, com movimento 

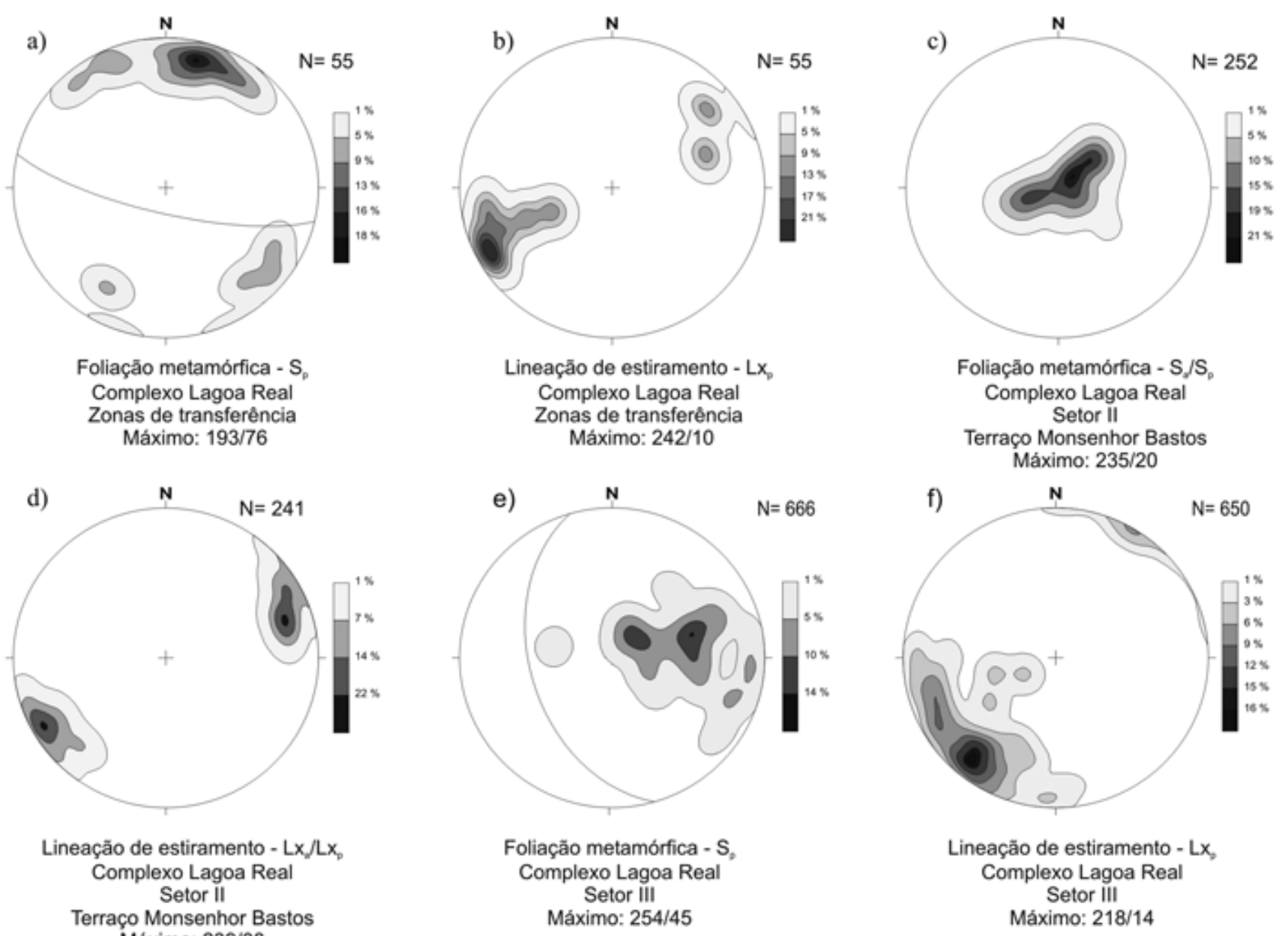

Figura 13 - Diagramas de projeção estereográfica (Hemisfério inferior) dos pólos da foliação metamórfica e da lineação de estiramento das zonas de transferência, do Terraço Estrutural Monsenhor Bastos e do setor III.

normal. Esse grupo de estruturas encontra-se, preferencialmente, nas porções filonitizadas pobres em ribbons de quartzo das zonas de cisalhamento dúctil-rúpteis da fase $\mathrm{D}_{\mathrm{p} 2}$ e aproveita planos de foliação do gnaisse Caetité. No Complexo Lagoa Real, tais zonas de cisalhamento possuem orientação 251/36, 059/63 e 263/47, nos setores I, II e III, com lineação de estiramento posicionadas em 254/52, 146/03 e 259/47, respectivamente (Fig. 15). Comparando os digramas das figuras 14 e 15, pode ser sugerido que houve um controle estrutural das estruturas pretéritas da fase compressional durante a nucleação das zonas de cisalhamento com movimentos normais.

Em um mesmo afloramento observam-se zonas de cisalhamento reversas normais. Nas zonas normais, as dobras isoclinais da fase $\mathrm{D}$ são desdobradas e essas estruturas, anteriormente paralelizadas com a foliação, assumem uma posição ortogonal com relação à foliação principal. Além disso, nos filonitos, a foliação oblíqua $\mathrm{S}$, das estruturas $\mathrm{S} / \mathrm{C}$ é rotacionada e se posiciona em alto ângulo com a foliação principal, C, enquanto nas encaixantes das zonas normais o ângulo entre aquelas estruturas permanece segundo $15^{\circ}$.
Associadas com a fase distensional, foram também encontradas estruturas fault propagation folds, que envolvem a foliação e o bandamento metamórfico. As dobras desenvolvidas, nesse caso, apresentam assimetria contrária àquela que é observada nas encaixantes. Uma outra feição associada com a fase distensional é a presença de dobras recumbentes, com charneira arredondada, desenvolvidas sobre a foliação compressional $\mathrm{S}_{\mathrm{p}}$. Essas dobras ocorrem, preferencialmente, nos gnaisses Caetité e atestam a atuação da compressão vertical que deu origem aos movimentos normais.

A fase $D_{e}$ é acompanhada por um metamorfismo regressivo, cuja associação mineralógica é representada por quartzo, epidoto, calcita, clorita e mica branca.

IDADES OBTIDAS NO COMPLEXO LAGOA

REAL Uma amostra do granitóide protomilonítico Cercado datada pelo método $\mathrm{Pb}-\mathrm{Pb}$. Foram analisadas duas frações de titanita. As duas frações são discordantes (Fig. 16), mas possuem idades ${ }^{207} \mathrm{~Pb} /{ }^{206} \mathrm{~Pb}$ semelhantes, cuja média é calculada em $1743 \pm 28 \mathrm{Ma}$ (Fig. 16). Essa é uma idade mínima para a cristalização das titanitas. Entretanto, considerando que as idades conhecidas 

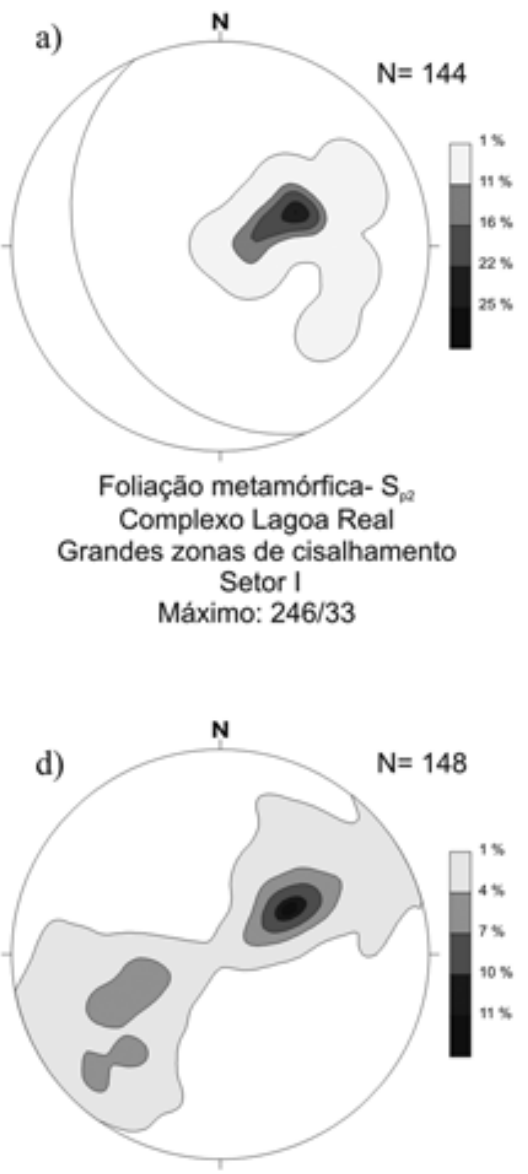

Lineação de estiramento - $L x_{0}$ Complexo Lagoa Real

Grandes zonas de cisalhamento Setor II

Máximo: 056/59

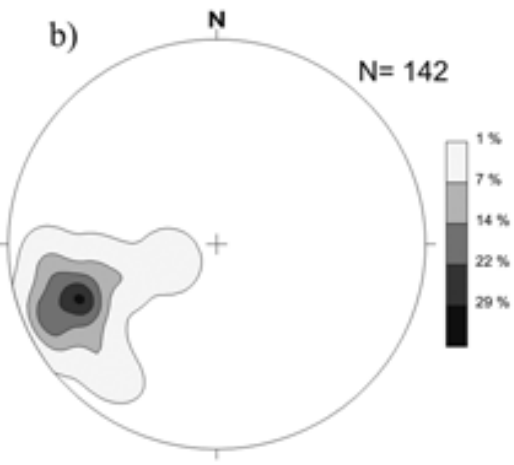

Lineaçăo de estiramento - $L x_{02}$ Complexo Lagoa Real Grandes zonas de cisalhamento Setor 1 Máximo: 247/29

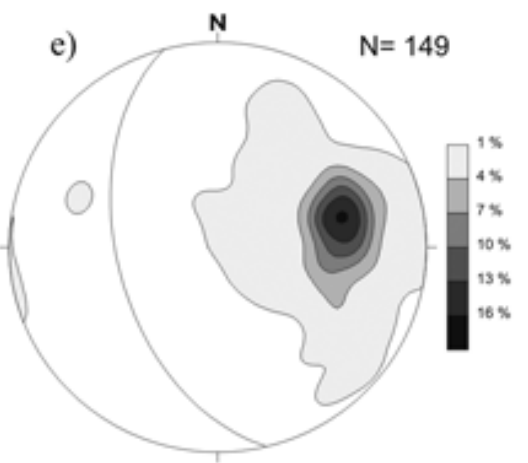

Foliação metamórfica - $\mathrm{S}_{22}$ Complexo Lagoa Real

Grandes zonas de cisalhamento Setor III Máximo: 256/51

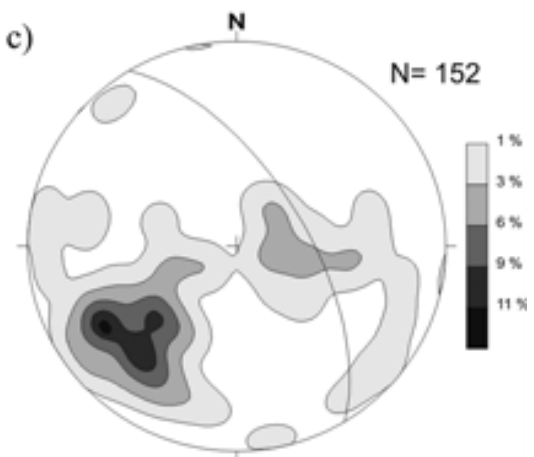

c)
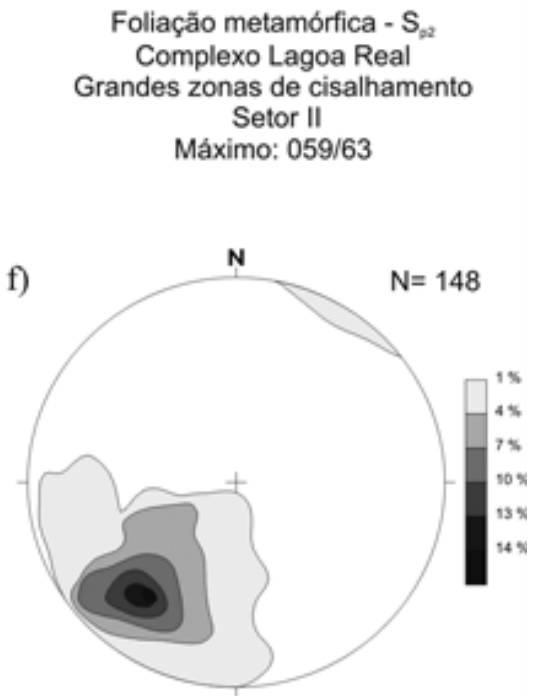

Lineação de estiramento - $L_{\mathrm{p} z}$ Complexo Lagoa Real Grandes zonas de cisalhamento Setor III Máximo: 220/30

Figura 14 - Diagramas de projeção estereográfica (Hemisfério inferior) dos pólos da foliação metamórfica e da lineação de estiramento das zonas de cisalhamento reversas nucleadas nos setores I, II e III.

para a cristalização do granito estão em torno de 1750 Ma (Turpin et al. 1988, Cordani et al. 1992), pode-se assumir a idade ${ }^{207} \mathrm{~Pb} / 206 \mathrm{~Pb}$ aqui obtida como muito próxima da idade real $(\mathrm{U} / \mathrm{Pb})$, e que sua cristalização se deu no episódio magmático. A perda de $\mathrm{Pb}$ é pouco intensa e deve estar ligada a processos de difusão secular do $\mathrm{Pb}$, pois as idades ${ }^{207} \mathrm{~Pb} /{ }^{206} \mathrm{~Pb}$ são próximas da idade $\mathrm{U} / \mathrm{Pb}$. Dessa forma, qualquer evento superimposto à rocha não atingiu temperaturas suficientes para abrir o sistema isotópico na titanita, cuja temperatura é estimada entre $550^{\circ}$ e $650{ }^{\circ} \mathrm{C}$.

EVOLUÇÃO DEFORMACIONAL DO COMPLEXO LAGOA REAL A partir da análise estrutural levada a efeito, e de acordo com a nomenclatura proposta por Cruz (2004), puderam-se identificar duas fases compressionais principais de deformação $\left(D_{a}, D_{p}\right)$ e uma distensional $\left(\mathrm{D}_{\mathrm{e}}\right)$ relacionadas com a evolução do Complexo Lagoa Real. Tais fases foram também encontradas por Cruz \& Alkmim (2006) no Corredor do Paramirim. Durante a primeira fase de deformação $\left(D_{a}\right)$
(Fig. 17), os movimentos foram predominantemente para norte e essa fase marca o início da inversão do Aulacógeno do Paramirim, no Neoproterozóico. Durante essa fase foi nucleada a Saliência do Rio Pardo, cujo limite mais ao norte estaria posicionada ao longo da zona de cisalhamento Brumado Caetité. Zonas de cisalhamento submeridianas com vergência para ENE e zonas de transferência sinistrais com orientação WSWENE são nucleadas durante a fase seguinte, $\mathrm{D}_{\mathrm{p}}$. Zonas de transferência destrais, como noticiada por Pascholati et al. (2003), não foram observadas em campo.

A fase $\mathrm{D}_{\mathrm{p}}$ subdivide-se nas etapas $\mathrm{D}_{\mathrm{p} 1}$ e $\mathrm{D}_{\mathrm{p} 2}$. A primeira nucleia zonas de cisalhamento dúcteis, responsáveis pela estruturação do Complexo Lagoa Real e pela transformação dos meta-granitóides São Timóteo em protomilonitos, milonitos e ultramilonitos, albititos e microclinitos. Nessa fase predomina condições de fácies anfibolito, marcada pela associação mineralógica e pelos processos deformacionais dúcteis e de recristalização sin-tectônica envolvendo os feldspatos. A variação na orientação dos eixos-c de quartzo e dos proces- 
a)

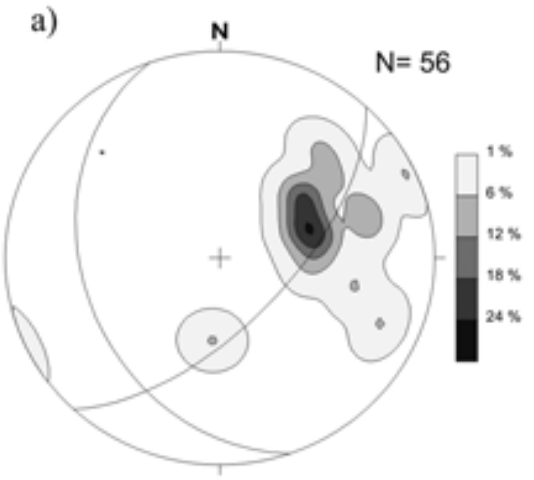

Foliaçăo metamórfica - S. Complexo Lagoa Real

Zonas de cisalhamento normal Setor I

Máximo: 251/36

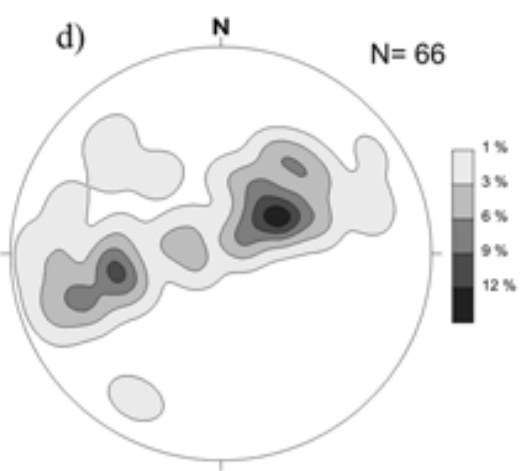

Lineação de estiramento - Lx。 Complexo Lagoa Real

Zonas de cisalhamento normal Setor II

Máximo: 146/03

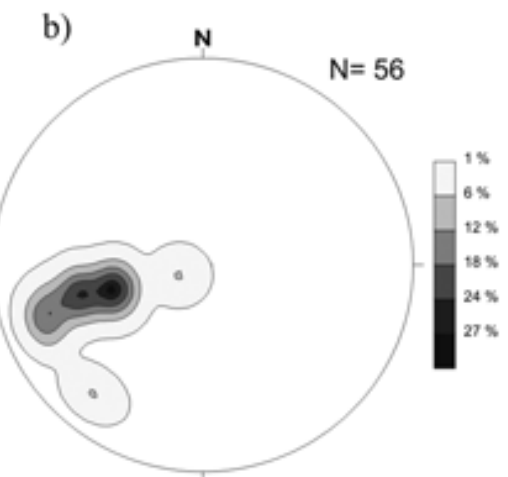

Lineação de estiramento - Lx, Complexo Lagoa Real Zonas de cisalhamento normal Setor I

Máximo: 254/52

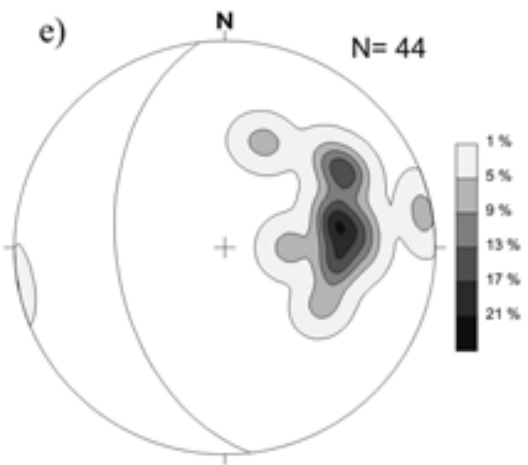

Foliação metamórfica - $\mathrm{S}$. Complexo Lagoa Real Zonas de cisalhamento normal Setor III

Máximo: 263/47

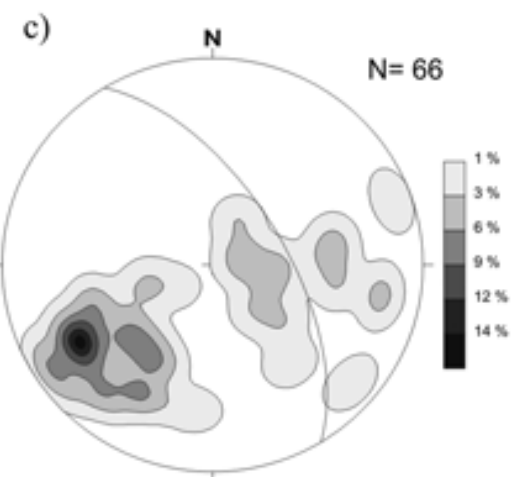

Foliação metamórfica - $\mathrm{S}$. Complexo Lagoa Real Zonas de cisalhamento normal Setor II Máximo: 059/63

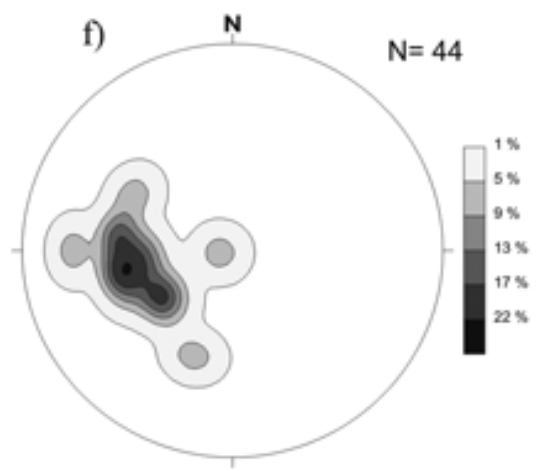

Lineaçăo de estiramento - Lx, Complexo Lagoa Real

Zonas de cisalhamento normal Setor III

Máximo: 259/47

Figura 15 - Diagramas de projeção estereográfica (Hemisfério inferior) dos pólos da foliação metamórfica e da lineação de estiramento das zonas de cisalhamento normais nucleadas nos setores I, II e III.

sos de deformação sintectônica envolvendo feldspatos sugerem que a temperatura da deformação cresce em direção a sul.

Na fase $\mathrm{D}_{\mathrm{p} 2}$, coaxial à $\mathrm{D}_{\mathrm{p} 1}$, são nucleadas e alojadas nas estruturas mais antigas do substrato do aulacógeno do Paramirim zonas de cisalhamento dúctilrúpteis. Os processos deformacionais verificados em zonas de cisalhamento, assim como a associação mineral e a distribuição dos eixos-c de quartzo sugerem condições de fácies xisto-verde.

Para ambas as fases, no setor I, os movimentos são frontais e com vergência para leste, tornandose oblíquos nos setores II e III. As estruturas da fase $\mathrm{D}_{\mathrm{p}}$, encontradas no Complexo Lagoa Real, podem ser observadas no embasamento, assim como nas rochas metassedimentares dos supergrupos Espinhaço e São Francisco que ocorrem na Chapada Diamantina, no Espinhaço Setentrional e na Saliência do Rio Pardo, tendo, por tanto, idade máxima neoproterozóica (Cruz \&
Alkmim 2006). O conjunto de estruturas formado nessa fase reflete um campo de tensões segundo WSE-ENE, com vergência para ENE, que refletiriam as colisões entre as placas São Francisco-Congo e Amazônia. De acordo com Cruz (2004), a mudança dos movimentos frontais, no setor I, para oblíquos, nos setores II e III está relacionado com a troca de posição entre $\sigma 2$ e $\sigma 3$ em função do aumento da profundidade do Aulacógeno do Espinhaço, em direção a sul. A vergência tectônica para oeste, sugerida por Pascholati et al. (2003), assim como o modelo de evolução tectônica apresentado pelos autores não são compatíveis com a distribuição das estruturas e cinemática observada ao longo das zonas de cisalhamento cartografadas.

A última fase deformacional, $\mathrm{D}_{\mathrm{e}}$, de natureza distensional, aproveita as estruturas previamente nucleadas e, possivelmente, reflete o colapso orogenético da Faixa Araçuaí, recentemente documentado por Alkmim et al. (2006). 


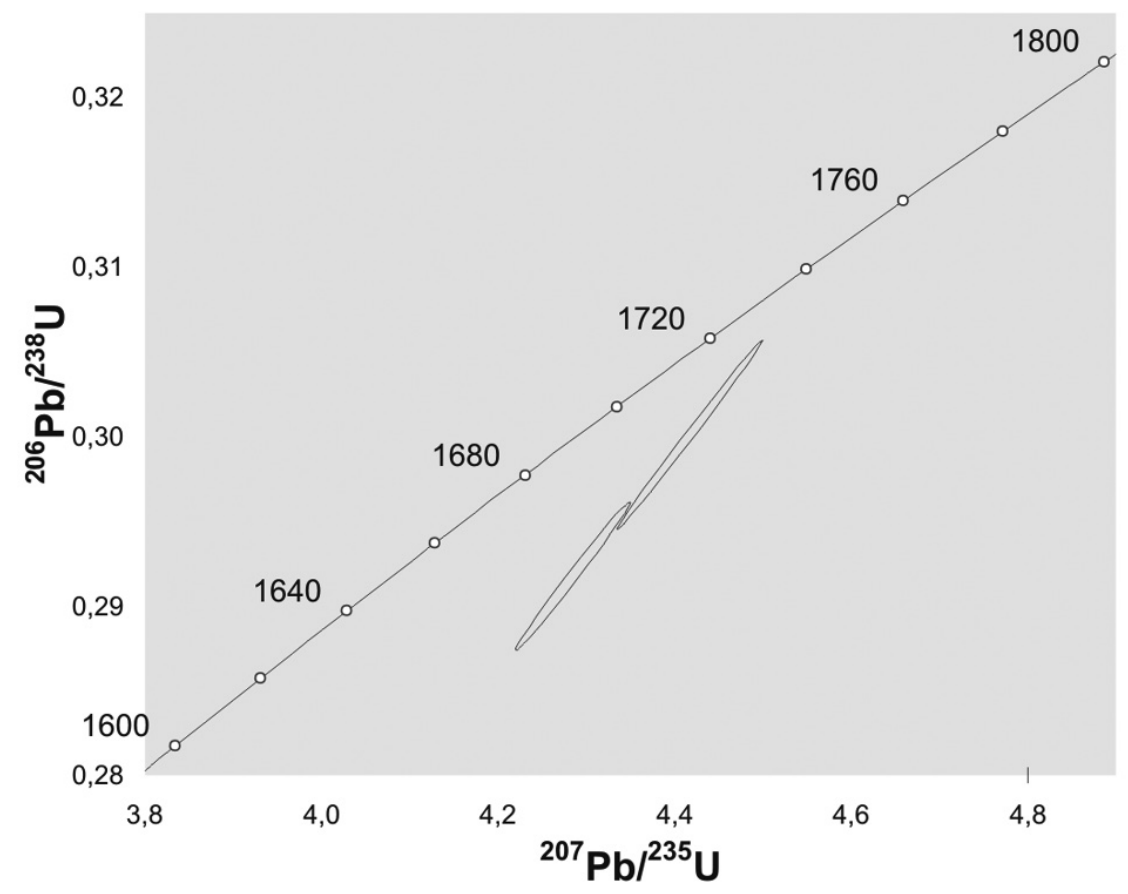

Figura 16 - Discórdia ${ }^{207} \mathrm{~Pb}{ }^{206} \mathrm{~Pb}$ obtida do granitóide protomilonítico Cercado.

Fase Da
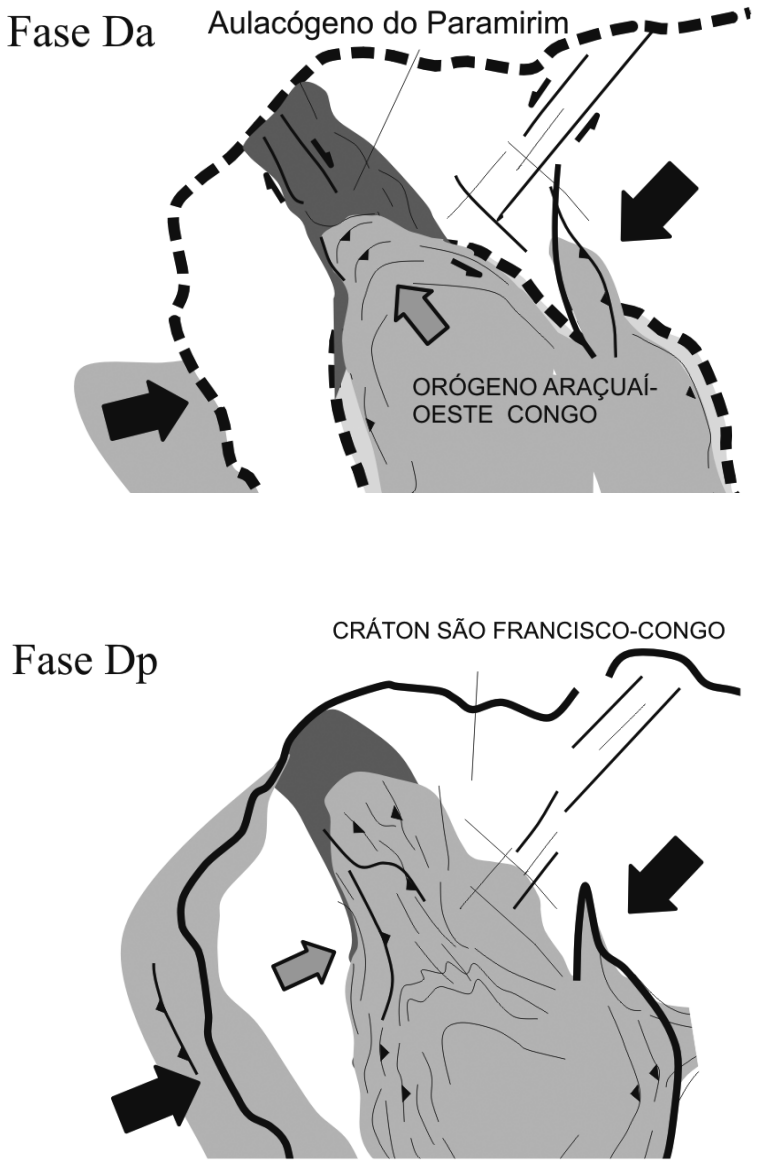

Fase De

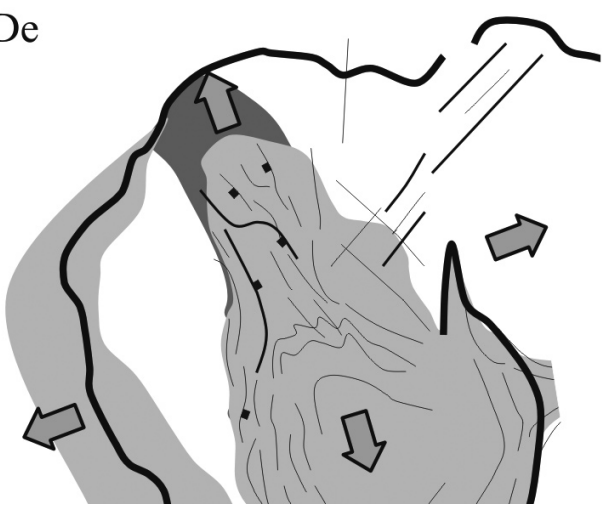

Áreas afetadas pela deformação brasiliana

$\nabla$ Vergência tectônica

Compressão Regional sin Da e Dp

Falhas reversas

Falhas normais

$\cdots+\cdots$. Futuro Cráton do São Francisco- Congo

Figura 17 - Modelo esquemático proposto para explicar a evolução tectônica do Corredor do Paramirim. Modificado de Cruz \& Alkmim (2006). 
CONCLUSÕES De acordo os dados obtidos pela análise estrutural e petrológica realizadas, pode-se concluir o seguinte:

(1) No Complexo Lagoa Real foram identificadas três fases deformacionais distintas, $\mathrm{D}_{\mathrm{a}}, \mathrm{D}_{\mathrm{p}}$ e $\mathrm{D}_{\mathrm{e}}$. As duas primeiras fases teriam sido resultados das colisões entre as placas São Franciscana e Amazônica, tendo vergências para NNE e ENE, respectivamente. A terceira fase, $D_{e}$, marcaria o colapso orogenético da Faixa Araçuaí.

(2) Os gnaisses e corpos lenticulares de albitito e microclinito foram gerados a partir de deformação de rochas granitóides, durante o estágio de deformação $\mathrm{D}_{\mathrm{p} 1}$.

(3) A geração dos granitos protomiloníticos Piripiri e Cercado, do augen gnaisse Lagoa Grande e do gnaisse Caetité, assim como dos albititos e microclinitos, e foi controlado tectonicamente e envolveu a deformação plástica dos feldspatos e do quartzo e a recristalização dessas fases minerais por intermédio da rotação de subgrãos. Por outro lado, a formação do granitóide protomilonítico Cercado envolveu processos de fragmentação de feldspatos.

(4) Processos envolvendo reações de hidrólise de feldspatos e a dissolução/precipitação do quartzo es- tão preferencialmente associados com fase $\mathrm{D}_{\mathrm{p} 2}$.

(5) Considera-se que o último evento deformacional, $\mathrm{D}$, foi acompanhado de retrometamosfismo e neoformação de calcita e epidoto, a partir das fases minerais pré-existentes.

(6) Com base nos dados estruturais regionais, considera-se para as deformações $\mathrm{D}_{\mathrm{a}}$ e $\mathrm{D}_{\mathrm{p}}$ uma idade máxima neoproterozóica.

Agradecimentos Os autores gostariam de expressar seus agradecimentos à Companhia Baiana de Pesquisa Mineral (CBPM), à Industrias Nucleares do Brasil (INB), à UFOP, à UFBA e à Companhia de Pesquisa de Recursos Minerais (CPRM-SUREG-Salvador) pelo apoio durante a realização desta pesquisa. Além disso, os autores agradecem aos revisores anônimos. S.C.P. Cruz foi contemplada pelo $\mathrm{CNPq}$ com uma bolsa durante o programa de Doutorado (Processo no 140739/2000-9) e de Pós-Doutorado Júnior (Processo no 150127/2005-7). Além disso, foi contemplada com Bolsa de Pós-Doutorado 1 da FAPESB (Termo de Outorga 2083/2006) e pelo Projeto Universal do CNPq (Processo 475092/2004-0). F.F.Alkmim recebe auxílio do CNPq na forma de bolsa de produtividade em pesquisa (Processo no 300833/99-7).

\section{Referências}

Alkmim F.F. 2004. O que faz de um cráton um cráton? O Cráton do São Francisco e as revelações almeidianas ao delimitá-lo. In: V. Mantesso-Neto, A. Bartorelli, C.D.R. Carneiro \& B.B. Brito-Neves (eds.) Geologia do Continente Sul-Amricano: Evolução da Obra de Fernando Flávio de Almeida, BECA, p. 17-36.

Alkmim F.F. \& Martins-Neto M. 2001. A Bacia intracratônica do São Francisco: Arcabouço estrutural e cenários evolutivos. In: C.P. Pinto \& M.A. Martins-Neto (eds.) Bacia do São Francisco: Geologia e Recursos Naturais. SBG/MG, Belo Horizonte, p. 9-30

Alkmim F.F., Brito Neves B.B. \& Alves J.A.C. 1993. Arcabouço tectônico do Cráton do São Francisco - uma revisão. In: J.M.L. Dominguez \& A. Misi (eds.) O Cráton do São Francisco. Reunião Preparatória do II Simpósio sobre o Cráton do São Francisco. Salvador, SBG/ Núcleo BA/SE/SGM/CNPq, p. 45-62.

Alkmim F.F., Marshak S., Pedrosa-Soares A.C., Peres G.G., Cruz S.C.P., Whittington A. 2006. Kinematic evolution of the Aracuaí-West Congo orogen in Brazil and Africa: Nutcracker tectonics during the Neoproterozoic assembly of Gondwana. Precambrian Res., 149:43-64.

Arcanjo J.B., Marques-Martins A.A., Loureiro H.S.C. \& Varela P.H.L. 2000. Projeto vale do Paramirim, escala 1:100.000. Programa de Levantamentos Geológicos Básicos do Brasil. CD-ROOM.

Barbosa J.S.F \& Dominguez J.M.L (Eds.) 1996. Mapa Geológico do estado da Bahia. Escala: 1.000.000. Texto explicativo, Salvador, $382 \mathrm{p}$.

Bastos-Leal L.R., Teixeira W., Cunha J.C. \& Macambira
M.J.B. 1997. Crustal evolution of Gavião block of the São Francisco Craton: A geochronological study with $\mathrm{U}-\mathrm{Pb}, \mathrm{Pb}-\mathrm{Pb}, \mathrm{Sm}-\mathrm{Nd}, \mathrm{Rb}-\mathrm{Sr}$ and K-Ar. In: South American Symposium on Isotope Geology, 2, Extended Abstract, p. 161-162.

Brito-Neves B.B., Cordani U.G. \& Torquato J.R. 1980. Evolução geocronológica do Precambriano no estado da Bahia. In: Inda H.A.D. \& Duarte F.B. Geologia e Recursos Minerais do Estado da Bahia, 3, SME-COM, p. 1-101.

Brito W., Raposo C. \& Matos E.C. 1984. Os albititos uraníferos de Lagoa Real. In: SBG, Cong. Bras.Geol., 33, Anais, p. 1475-1488.

Cordani U.G., Iyer S.S., Taylor P.N., Kawashita K., Sato K. \& Mcreath I. 1992. Pb-Pb, Rb-Sr, and K-Ar sistematic of the Lagoa Real uranium province (south-central Bahia, Brazil) and the Espinhaço Cycle (ca. 1.5-1.0 Ga). J. South Am. Earth Sci., 1:33-46.

Costa P.H.O., Andrade A.R.F., Lopes G.A. C. \& Souza S.L. 1985. Projeto Lagoa Real-Mapeamento Geológico 1:25.000. CBPM/NUCLEBRAS/SME, v.1, 455 p.

Cruz S.C.P. 2004. Tectônica do Embasamento na Porção Sul do Corredor do Paramirim-MG/BA e sua relação com o orógeno Araçuai-Oeste Congo. Tese de Doutorado, Departamento de Geologia, Universidade Federal de Ouro Preto, $505 \mathrm{p}$.

Cruz S.C.P. \& Alkmim F.F. 2002. O Arcabouço Estrutural dos Gnaisses Lagoa Real na Porção Sul do Corredor do Paramirim (BA): Evidencias do Envolvimento do Embasamento do Cráton do São Francisco durante a Interação Brasiliana entre o Corredor 
do Paramirim e a Faixa Araçuaí - Oeste Congo. In: SBG/NNE, Cong. Bras.Geol., 46, Anais., p. 301.

Cruz S.C.P. \& Alkmim F.F. 2006. The tectonic interaction between the Paramirim Aulacogen and the Araçuaí Belt, São Francisco Craton region, Easter Brazil. An. Acad. Bras. Ciênc., 1:151-173.

Danderfer $\mathrm{F}^{\circ}$.A. 2000. Geologia sedimentar e evolução tectônica do Espinhaço Setentrional, estado da Bahia. Tese de Doutorado, Instituto de Geociências, Universidade Federal de Brasília, 497 p.

Fernandes P.E.C.A., Montes M.L., Braz E.R.C., Silva L.L., Oliveira F.L.L., Ghignone J.I., Siga Jr. O. \& Castro H.E.F. 1982. Geologia. In: BRASIL. Ministério das Minas e Energia. Secretaria Geral. Projeto RADAMBRASIL. Folha SD.23 Brasília: geologia, geomorfologia, pedologia, vegetação e uso potencial da terra. Rio de Janeiro, p. 25-204.

Guimarães J.T. 1996. A Formação Bebedouro no estado da Bahia: Faciologia, Estratigrafia e Ambiente de Sedimentação. Dissertação de Mestrado, Instituto de Geociências, Universidade Federal da Bahia, 155 p.

Lobato L.M. 1985. Metamorphism, metassomatism and mineralization at Lagoa Real, Bahia, Brazil. Doctoral Thesis, University Western Ontario, 306 p.

Lobato L. \& Fyfe W. 1990. Metamorphism and mineralization at Lagoa Real, Bahia, Brasil. Econ. Geol., 5:968989.

Marinho M.M. 1991. Le sequence Volcano-Sedimentaire de Contendas Mirante et la Bordure Ocidentale du Bloc de Jequié (craton du São Francisco, Brésil): um example de transition Archeen-Proterozoic. These de doctorat, Université de Clemont-Ferrand, $257 \mathrm{p}$.

Maruèjol P., Cuney M., Fuzikawa K., Maria Netto A. \& Poty B. 1987. The Lagoa Real Subalkaline Granitic Complex (South Bahia, Brazil): A Source for Uraniun Mineralizations Associated With Na-Ca Metassomatism. Rev. Bras. Geoc., 4:578-594.

McReath I., Jardim de Sá E. F., Fryer B. J. 1981. As vulcânicas ácidas da região da Bacia do rio Paramirim-Bahia. In: H.A.V. Inda, M.M. Marinho, F.P. Duarte (eds.) Geologia e Recursos Minerais do Estado da Bahia, Textos Básicos, 4, SME/COM, p.120-130.

Misi A. \& Veizer J. 1996. Chemostratigraphy of neoproterozoic carbonate sequences of the Una Group, Irecê Basin, Brazil. In: SBG/NBA-SE, Cong. Bras.Geol., 39, Anais, v. 5, p. 487-489.

Pascholati E.M., Silva C.L., Costa S.S., Osako L.S., Amaral G. \& Rodriguez I.P. 2003. Novas ocorrências de urânio na região de lagoa real, a partir da superposição de dados geofísicos, geológicos e de sensoriamento remoto. Revista Brasileira de Geociencias, 33(2-Suplemento):9198.

Pedrosa-Soares A.C. \& Wiedeman-Leonardos C. 2000. Evolution of the Araçuaí belt and its connection to the Ribeira belt, eastern Brazil. In: U.G. Cordani, E.J. Milani, A.
Thomaz Filho \& D.A. Campos (eds.) Tectonic Evolution of South America. Rio de Janeiro, Brazil, p. 265-285.

Pedrosa-Soares A.C.P., Noce C.M., Vidal P.H., Monteiro R.L.B.P. \& Leonardos O.H. 1992b. Toward a new model for the Late Proterozoic Araçuaí (SE Brazil) - West Congolian (SW Africa) Belt. J. South Am. Earth Sci., , 1/2: 22-47.

Pedrosa-Soares A.C., Noce C.M., Vidal P. \& Monteiro R.L.B.P. 1992a. Discussão sobre o novo modelo tectônico para a Faixa Araçuaí-Oeste Congolesa. Rev. Esc. Minas, 1-2:38-40.

Pedrosa-Soares A.C., Noce C.M., Wiedemann C.M. \& Pinto C.P. 2001. The Araçuaí-West-Congo Orogen in Brazil: an overview of a confined orogen formed during Gondwanaland assembly. Precambrian Res., 1-4:307-323.

Pimentel M.M., Machado N. \& Lobato L.M. 1994. Geocronologia $\mathrm{U} / \mathrm{Pb}$ de rochas graníticas e gnáissicas da região de Lagoa Real, Bahia, e implicações para a idade da mineralização de urânio. In: SBG, Cong. Bras.Geol., 38, Boletim de Resumos Expandidos, p. 389-390.

Prates S.P. \& Fuzikawa K. 1984. Aspectos petrográficos da jazida uranífera de Lagoa da Rabicha, Bahia. In: SBG, Cong. Bras.Geol., 33, Salvador, Anais, p. 25-54.

Raposo C. \& Matos E.C. 1982. Distrito uranífero de Lagoa Real - A história de um exemplo. In: SBG, Cong. Bras. Geol., 32, Anais, p. 2035-2047

Raposo C., Matos E. C. \& Brito W. 1984. Zoneamento cálcio-sódico nas rochas da província uranífera de Lagoa Real. In: SBG, Congresso Brasileiro de Geologia, 33, Anais, p. 1489-1502.

Ribeiro C.I., Carvalho Filho C.A. \& Hashizume S. 1984. As jazidas de urânio de Lagoa Real. Cong. Bras.Geol., 33, Anais, p. 1463-1474.

Schobbenhaus C. 1996. As tafrogêneses superpostas Espinhaço e Santo Onofre, estado da Bahia: Revisão e novas propostas. Rev. Bras. Geoc., 4:265-276.

Schobbenhaus C., Campos D.A., Derze G.R. \& Asmus H.E. 1981. Mapa Geológico do Brasil e da Área Oceânica Adjacente, Incluindo Depósitos Minerais (Escala 1:2.500.000). Brasília, DNPM.

Sibson R.H. 1977. Fault rocks and fault mechanisms. J. Geol. Soc. London, 133:197-213.

Sobrinho E.G., Raposo C., Alves J.V., Brito W. \& Vasconcelos T.G. 1980. O distrito uranífero de Lagoa Real, Bahia. In: SBG, Cong. Bras. Geol., 31, Anais., p. 1499-1512.

Teixeira L.R. 2000. Relatório Temático de Litogeoquímica. Projeto vale do Paramirim., Salvador, CPRM/CBPM, $35 \mathrm{p}$.

Turpin L., Maruèjol P. \& Cuney M. 1988. U-Pb, Rb-Sr and Sm-Nd chronology of granitic basement, hydrotermal albitites and uranium mineralization, Lagoa Real, South Bahia, Brazil. Contrib. Mineral. Petrol., 98:139-147.

Manuscrito CSF-20

Submetido em 31 de maio de 2006 Aceito em 01 de março de 2007 